\title{
Clinical utility of plasma progesterone and blood and plasma glucose concentrations in predicting parturition in Holstein cows
}

\author{
M. W. H. Hiew, ${ }^{1,2}$ A. A. Megahed, ${ }^{1,3} \odot$ L. A. Horstman, ${ }^{1}$ and P. D. Constable ${ }^{1,4 *}$ (1) \\ ${ }^{1}$ Department of Veterinary Clinical Science, College of Veterinary Medicine, Purdue University, West Lafayette, IN 47907 \\ ${ }^{2}$ Department of Veterinary Clinical Studies, Faculty of Veterinary Medicine, Universiti Putra, Selangor 43400, Malaysia \\ ${ }^{3}$ Department of Animal Medicine, Internal Medicine, Faculty of Veterinary Medicine, Benha University, Moshtohor-Toukh, Kalyobiya 13736, Egypt \\ ${ }^{4}$ Department of Veterinary Clinical Medicine, College of Veterinary Medicine, University of Illinois at Urbana-Champaign 61802
}

\begin{abstract}
An accurate, practical, and low-cost method for predicting parturition is urgently needed in the dairy industry. The objective of this study was to evaluate changes in plasma progesterone concentration ([prog]) and glucose concentration in whole blood $\left([\mathrm{gluc}]_{\mathrm{b}}\right)$ and plasma $\left([\mathrm{gluc}]_{\mathrm{p}}\right)$ as predictors of parturition within 6 , 12 , and $24 \mathrm{~h}$ in primiparous and multiparous Holstein cows. Blood samples were obtained daily at approximately $0900 \mathrm{~h}$ from 34 primiparous and 72 multiparous Holstein cows in late gestation and the time of calving recorded to the nearest hour. Plasma [prog] was measured using an ELISA, and [gluc $]_{\mathrm{b}}$ and $[\mathrm{gluc}]_{\mathrm{p}}$ using a low-cost point-of-care glucose meter. The optimal cut-point for predicting parturition was determined using binomial logistic regression with general estimating equations, because the data set consisted of repeated measures for each cow. Diagnostic test performance was evaluated by comparing the area under the receiver operating characteristic curve (AUC) and calculating the sensitivity, specificity, and $\kappa$ at the optimal cut-point for predicting parturition. Plasma [prog] was the most accurate predictor of parturition within $24 \mathrm{~h}(\mathrm{AUC}=$ $0.96)$ and $12 \mathrm{~h}(\mathrm{AUC}=0.93)$, whereas $[\mathrm{gluc}]_{\mathrm{b}}$ was the most accurate predictor of parturition within $6 \mathrm{~h}$ (primiparous, $\mathrm{AUC}=0.96$; multiparous, $\mathrm{AUC}=0.86)$. We conclude that a decrease in plasma $[\mathrm{prog}]$ is currently the most accurate test for predicting calving within 24 h. Measurement of $[\mathrm{gluc}]_{\mathrm{b}}$ is a promising new test for the cow-side prediction of parturition in dairy cows due to its accuracy, practicality, and low cost.
\end{abstract}

Key words: hyperglycemia, hypercortisolemia, fetal stress, dystocia, hypocalcemia

Received October 27, 2019.

Accepted February 13, 2020.

*Corresponding author: constabl@illinois.edu

\section{INTRODUCTION}

An accurate, practical, and low-cost method for predicting parturition based on hormonal, physiologic, anatomic, and behavioral changes is urgently needed in the dairy industry. Hormonal changes that indicate impending parturition include decreased plasma progesterone concentration ([prog] $]$ ), increased plasma estrone sulfate and estradiol-17 $\beta$ concentrations, and increased plasma cortisol concentration ([cortisol]; Hudson et al., 1976; Matsas et al., 1992; Shah et al., 2006). Physiologic and anatomic changes that indicate parturition is imminent include decreased rectal, vaginal, reticular, tail base, and ear temperature, sacrosciatic ligament relaxation, vulvar edema, the presence of a clear or bloody vaginal discharge, distention of the udder and teats, and the presence of udder edema (Dufty, 1971; Birgel et al., 1994; Streyl et al., 2011), as well as changes in electrolyte concentrations in mammary gland secretions (Bleul et al., 2006). Behavioral changes associated with restlessness are predictive of impending parturition, including frequent tail-raising (Miedema et al., 2011), increased number of steps, increased incidence of lying activity, and decreased eating and rumination time (Saint-Dizier and ChastantMaillard, 2015; Lange et al., 2017).

Plasma [prog] is widely viewed as the most accurate predictor of parturition in cattle, because it remains stable for much of the last trimester and decreases rapidly 12 to $36 \mathrm{~h}$ before calving (Matsas et al., 1992; Birgel et al., 1994; Streyl et al., 2011). The decrease in plasma [prog] is viewed as the initiator of parturition from the maternal perspective, because the decrease removes the "progesterone block" on uterine motility, permitting organized myometrial contractions and initiation of the first stage of parturition (Gillette, 1966; Kindahl et al., 2004). Interestingly, the time before parturition that plasma [prog] first decreases has not been accurately identified, and the diagnostic usefulness of decreased plasma $[\mathrm{prog}]$ in predicting parturition in cattle has not 
been formally evaluated. Plasma [cortisol] starts to increase 25 to $32 \mathrm{~h}$ before parturition, concomitant with the decrease in plasma [prog]; it peaks immediately at the time of fetal expulsion and rapidly decreases within the following hour (Hudson et al., 1976; Patel et al., 1996). Although a marked increase in fetal plasma [cortisol] appears to play a central role in initiating parturition in ruminants (Hudson et al., 1976; Kindahl et al., 2004; Shenavai et al., 2012), the periparturient increase in maternal plasma [cortisol] is unrelated to fetal hypercortisolemia (Patel et al., 1996). Plasma glucose concentration $\left([\mathrm{gluc}]_{\mathrm{p}}\right)$ is increased on the day of parturition (Godden and Allcroft, 1932; Schwalm and Schultz, 1976; Bionaz et al., 2007), presumably in response to hypercortisolemia. Maternal hypercortisolemia is a common physiologic response to stress and pain, and sympathetic nervous system activation results in hyperglycemia due to increased gluconeogenesis and decreased glucose utilization (Constable et al., 2017). It is therefore likely that periparturient hyperglycemia during the first stage of parturition in cattle is due to pain associated with the onset of myometrial contractions and is augmented by the efforts required for fetal expulsion during the second stage of parturition (Hudson et al., 1976). Although $[\mathrm{gluc}]_{\mathrm{p}}$ is increased at the time of parturition, we are not aware of any studies that have documented the clinical utility of using an increase in $[\mathrm{gluc}]_{\mathrm{p}}$ or whole blood glucose concentration ([gluc $]_{\mathrm{b}}$ ) to predict parturition in cattle. This issue is relevant because $[\mathrm{gluc}]_{\mathrm{b}}$ can be practically, inexpensively, and accurately measured cow-side using whole blood and a point-of-care device (Megahed et al., 2015).

Based on the above, we hypothesized that plasma [prog] starts to decrease at approximately $36 \mathrm{~h}$ before parturition; that the relationship between plasma [prog] and time before parturition is similar in primiparous and multiparous Holsteins; and that plasma [prog] has clinical utility in predicting parturition in late-gestation Holsteins. We also hypothesized that plasma [cortisol], $[\mathrm{gluc}]_{\mathrm{p}}$, and $[\mathrm{gluc}]_{\mathrm{b}}$ increase concurrently in the 6 to 12 $\mathrm{h}$ before parturition, and that increases in [gluc $]_{\mathrm{b}}$ and [gluc $]_{\mathrm{p}}$ are predictive of parturition. The first objective of this study was to accurately characterize and compare the relationship between plasma [prog] and time in late-gestation primiparous and multiparous Holsteins. The second objective was to determine and compare the ability of plasma [prog] to predict parturition within 6 , 12 , and $24 \mathrm{~h}$ in primiparous and multiparous Holsteins. The third objective was to accurately characterize and compare the relationships between plasma [cortisol], ggluc $_{\mathrm{b}}$, [gluc $]_{\mathrm{p}}$, and time in late-gestation primiparous and multiparous Holsteins. The fourth objective was to determine the ability of $[\text { gluc }]_{\mathrm{b}}$ and $[\mathrm{gluc}]_{\mathrm{p}}$ to predict parturition within 6,12 , and $24 \mathrm{~h}$ in late-gestation Holstein cows.

\section{MATERIALS AND METHODS}

All methods were approved by the Purdue University Institutional Animal Care and Use Committee. The study reported here was part of a larger study investigating the prediction of parturition and dystocia, and energy and calcium homeostasis in the periparturient period in Holstein-Friesian cows. Additional results have been published elsewhere (Megahed et al., 2015; Hiew et al., 2016; Megahed et al., 2017; Megahed et al., 2018a; Megahed et al., 2018b; Megahed et al., 2019).

\section{Animals, Housing, and Feeding}

We enrolled a convenience sample of 106 late-gestation non-lactating Holstein-Friesian cattle (34 primiparous and 72 multiparous) from the Purdue University Dairy Research and Education Center between May 29, 2012, and March 29, 2013. During the study, 240 animals calved; we did not enroll 134 of these because of workload constraints. Enrolled cattle were moved from the outdoor dry lot to indoor, temperature-controlled individual box stalls $(10 \mathrm{ft} \times 10 \mathrm{ft}) 4 \mathrm{~d}$ before their estimated parturition date (d 0). All animals were deemed healthy based on a routine physical examination. They were fed an acidogenic TMR based on formulations for dry cows from the National Research Council (NRC, 2001). The TMR was fed once daily between 0800 and $0930 \mathrm{~h}$. Cattle were given ad libitum access to water at all times. After calving, all cows were kept in the same individual box stalls or tie stalls for $3 \mathrm{~d}$ or until they recovered from any postpartum health issues, and then they were moved to a freestall. Cows were switched to a lactating-cow TMR after calving based on fresh-cow formulations recommended by the National Research Council (NRC, 2001). Ration analyses are presented in Megahed et al. (2018b).

\section{Experimental Study}

Physical examinations were performed daily between 0800 and $1000 \mathrm{~h}$, with the animal gently restrained in a headlock. Blood samples were obtained daily at approximately 0900 from the coccygeal vessels using 20-gauge Vacutainer needles, Vacutainer holders, and 10-mL lithium heparin blood collection tubes (BD Diagnostics, Franklin Lakes, NJ). We intended to collect blood samples on days $-4,-3,-2,-1,0$, and +1 relative to the day of calving (defined as d 0). Specifi- 
cally, if a cow calved in early morning between 0000 $\mathrm{h}$ and 0829 , the blood sample obtained at $0900 \mathrm{~h}$ was labeled as being d 0; whereas if a cow calved between 0930 and $2359 \mathrm{~h}$, the blood sample obtained at 0900 $\mathrm{h}$ was labeled as being $\mathrm{d}-1$. Some cows calved earlier than anticipated, the result being that samples were not available for all prepartum days.

The calf and dam were separated within a few hours of calving. The time of calving (defined as complete expulsion of the fetus) was recorded to the nearest hour, and data collected were then binned into 6,12 , or $24 \mathrm{~h}$ intervals relative to the time of calving.

\section{Analytical Methods}

A handheld electronic blood glucose meter (Precision Xtra Blood Glucose and Ketone Monitoring System; Abbott Diabetes Care Inc., Chicago, IL) was used to measured $[\text { gluc }]_{\mathrm{b}}$ and $[\text { gluc }]_{\mathrm{p}}$. This meter was validated in our laboratory (Megahed et al., 2015). A drop of non-heparinized blood from the tip of the vacutainer needle was applied immediately to the sensor of a blood glucose test strip that was inserted in the meter to measure $[\mathrm{gluc}]_{\mathrm{b}}$. Heparinized blood samples were centrifuged for $5 \mathrm{~min}$ at $1,300 \times g$ within $30 \mathrm{~min}$ of collection to separate plasma from cells and minimize glucose metabolism. Plasma was harvested within $1 \mathrm{~h}$ of centrifugation, and $[\mathrm{gluc}]_{\mathrm{p}}$ was measured using the same method as described for $[\text { gluc }]_{b}$. We calculated [gluc $_{\mathrm{p}}$ in $\mathrm{mg} / \mathrm{dL}$ from the measured concentration using the following validated equation: $[\mathrm{gluc}]_{\mathrm{p}}=0.66 \times$ $[\text { gluc }]_{\text {p-measured }}+15$ (Megahed et al., 2015). The time

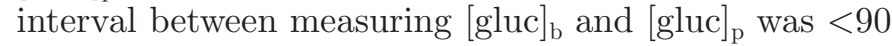
min.

The remaining plasma was stored at $-20^{\circ} \mathrm{C}$ in polypropylene vials until analyzed. Plasma [prog] was determined in duplicate using thawed plasma samples and an ELISA validated for cattle (Ovucheck Plasma ELISA kit; Biovet Inc., Saint-Hyacinthe, Quebec, Canada) according to the manufacturer's directions. The plasma [prog] value we used for statistical analysis was the mean of the 2 measurements. The interassay CV from 20 assays at plasma $[\mathrm{prog}]=3.3 \mathrm{ng} / \mathrm{mL}$ was $22.6 \%$, and at plasma $[\mathrm{prog}]=6.9 \mathrm{ng} / \mathrm{mL}$ was $14.9 \%$ (Semambo et al., 1992). Plasma [cortisol] was determined using a RIA (Coat-A-Count Cortisol; Siemens, Los Angeles, CA) according to the manufacturer's directions (Proverbio et al., 2013). The mean intra-assay $\mathrm{CV}$ was $4.2 \%$, the mean interassay CV was $6.0 \%$, percent recovery ranged from 107 to $125 \%$, and the limit of quantitation was 2.5 $\mathrm{ng} / \mathrm{mL}$ in calf plasma (Erkens et al., 1998).

\section{Progesterone Concentration-Time Relationship}

We used mixed-model segmented nonlinear regression (PROC NLMIXED, SAS 9.4, SAS Institute Inc., Cary, NC; Gonçalves et al., 2016; Trefz et al., 2018) to characterize the plasma [prog]-time relationship during the last $3 \mathrm{~d}$ of gestation and the first $24 \mathrm{~h}$ after parturition. This permitted adjustment for the effect of cow on the model estimates, because up to 4 data points were obtained from each cow. A mixed-model approach using the adaptive Gauss-Hermitage quadrature approximation method for the marginal likelihood function was applied using quasi-Newton optimization, with $\mu_{0}$ representing the random background coefficient assuming the distribution of random effects to be normal, with mean $\left(\mu_{0}\right)=0$ and variance $=\mathrm{s} 2 \mathrm{e}$. Based on plasma [prog]-time relationships in other studies over the same time interval related to parturition (Matsas et al., 1992; Birgel et al., 1994), model equations assumed a constant value for plasma $[\mathrm{prog}]$ when time $(\mathrm{t}) \leq$ the cut-point identified by segmented regression $\left(\mathrm{X}_{\mathrm{c}}\right)$ and a negative exponential relationship between plasma [prog] and time when $\mathrm{t}>\mathrm{X}_{\mathrm{c}}$, such that $[\mathrm{prog}]=\left(\mathrm{b}_{0}+\right.$ $\left.\mu_{0}\right)$ when $\mathrm{t} \leq \mathrm{X}_{\mathrm{c}}$, and $[\mathrm{prog}]=\left(\mathrm{b}_{0}+\mu_{0}\right) \times e^{[-\mathrm{b} 1 \times(\mathrm{t}-\mathrm{Xc})]}$ when $t>X_{c}$. Segmented nonlinear regression permitted objective identification of the hour before parturition when plasma [prog] started to decrease. Accurate identification of this time is clinically important, because the decrease in plasma [prog] appears to be the first detectable maternal signal that indicates parturition is imminent.

\section{Glucose and Cortisol Concentration- Time Relationships}

Mixed-model segmented linear regression (PROC NLMIXED, SAS 9.4) was used to characterize the gluc $_{\mathrm{b}}$ and $[\mathrm{gluc}]_{\mathrm{p}}$-time relationships during the last 4 $\mathrm{d}$ of gestation, adjusting for the effect of cow. We used a model-fitting approach similar to that described for the plasma [prog]-time relationship, but using different model equations. Model equations assumed a constant $[\mathrm{gluc}]_{\mathrm{b}}$ and $[\mathrm{gluc}]_{\mathrm{p}}$ when time $(\mathrm{t})$ was greater than or equal to the cut-point identified by segmented regression $\left(\mathrm{X}_{\mathrm{c}}\right)$ and a positive linear relationship between $[\text { gluc }]_{\mathrm{p}}$, [gluc $]_{\mathrm{b}}$, or [cortisol] and $\mathrm{t}$ when $\mathrm{t}>\mathrm{X}_{\mathrm{c}}$, such that $[$ gluc $]=\left(\mathrm{b}_{0}+\mu_{0}\right)$ when $\mathrm{t} \leq \mathrm{X}_{\mathrm{c}}$, and $\left[\mathrm{b}_{0}+\right.$ $\left.\mu_{0}+b_{1} \times\left(t-X_{c}\right)\right]$ when $t>X_{c}$. Segmented linear regression permitted objective identification of the hour before parturition when $[\mathrm{gluc}]_{\mathrm{b}}$ and $[\mathrm{gluc}]_{\mathrm{p}}$ started to increase. 


\section{Statistical Analysis}

SAS software (version 9.4) and MedCalc Statistical Software (version 19.0.7; MedCalc Software bvba, Ostend, Belgium) were used to analyze the data; $P<$ 0.05 was considered significant. Relationships between [gluc $_{\mathrm{p}}$, [gluc $]_{\mathrm{b}}$, and plasma [cortisol] in the $12 \mathrm{~h}$ before to $12 \mathrm{~h}$ after parturition, consisting of 1 data point per cow, were evaluated using Pearson's coefficient. This time interval was selected for analysis because of the large range of values for plasma [cortisol] (Hudson et al., 1976).

Analysis of clustered binary data - such as repeated measurement of plasma [prog], [gluc $]_{\mathrm{p}}$, and $[\text { gluc }]_{\mathrm{b}}$ over time - needs to account for the clustering of data within cow, because values from the same cow are likely to be positively correlated (Costa et al., 2016). Therefore, we analyzed the clustered data by fitting marginal generalized estimating equation (GEE) regression models. This method provides valid inferences for population average effects and covariates such as parity (Ballinger, 2004; Schober and Vetter, 2018). We calculated binomial logistic regression models using PROC GENMOD (SAS 9.4) with a repeated statement, binomial distribution for the response variable, a logit link function, and an autoregressive(1) covariance structure, selected based on the lowest value for quasilikelihood under the independence model criterion and because we were analyzing longitudinal data. We developed receiver operating characteristic curves and calculated 95\% Wald confidence limits for the area under the curve (AUC). The AUC provides the best overall measure of diagnostic test performance (Zweig and Campbell, 1993), and a Wald $P<0.05$ indicates that the test result is significantly better than a chance result. Values for AUC $>0.9$ typically indicate a highly accurate diagnostic test; AUC values of 0.7 to 0.9 indicate moderate accuracy, 0.5 to 0.7 low accuracy, and 0.5 a chance result (Swets, 1988). The adequacy of the logistic regression model fit was evaluated using plots of deviance influence statistics against the predicted values.

Test performance was also summarized by obtaining estimates for test sensitivity (Se) and specificity (Sp). Youden's index was calculated to identify the optimal cut-point (the value point where the following expression has its maximum value: $\mathrm{Se}+\mathrm{Sp}-1$ ) for plasma [prog], [gluc $]_{\mathrm{b}}$, and $[\mathrm{gluc}]_{\mathrm{p}}$ to predict calving within 6 , 12 , and $24 \mathrm{~h}$. This analytical method equally weighed the values of Se and Sp. Estimates for Se and Sp and their $95 \%$ confidence interval (CI) were calculated using the identified cut-point. The positive likelihood ratio $(+\mathbf{L R})$ was calculated as: $+\mathrm{LR}=\mathrm{Se} /(1-\mathrm{Sp})$. Values for $+\mathrm{LR}>10$ indicate that a positive test is good at predicting an event such as parturition (Grimes and Schulz, 2005). The $\kappa$ coefficient (PROC FREQ, SAS 9.4) was calculated using the cut-point to characterize the level of agreement between the test prediction of calving within 6,12 , and $24 \mathrm{~h}$ and actual calving time. Values for $\kappa<0.2$ indicate poor agreement, whereas $0.2<\kappa<0.4$ indicates fair agreement, $0.4<\kappa<0.6$ indicates moderate agreement, $0.6<\kappa<0.8$ reflects good agreement, and $\kappa>0.8$ indicates excellent agreement (Landis and Koch, 1977).

\section{RESULTS}

\section{Plasma Progesterone Concentration- Time Relationship}

We found no difference in the plasma [prog]-time relationship between primiparous and multiparous Holsteins (see following section). Mixed-model segmented nonlinear regression indicated that plasma [prog] remained constant at $6.60 \mathrm{ng} / \mathrm{mL}$ (95\% CI 6.33 to 6.87 ) until $1.47 \mathrm{~d}$ (95\% CI -1.56 to -1.39$)$ or $35 \mathrm{~h}$ before parturition (Figure 1). Plasma [prog] decreased in an exponential manner after this, such that $[\mathrm{prog}]=6.60$ $\times e^{[-0.79 \times(t+1.47)]}$. The $95 \%$ CI for the exponential coefficient $\left(b_{1}\right)$ was 0.71 to 0.87 .

\section{Plasma Progesterone Concentration: Prediction of Calving}

At least 3 stored plasma samples were available before calving (d 0) for 71 Holsteins (19 primiparous, 52 multiparous), providing a total of 224 data points to evaluate the clinical utility of plasma [prog] for predicting parturition within 6,12 , or $24 \mathrm{~h}$. Calving did not occur evenly through the $24 \mathrm{~h}$ of each day; the highest incidence of calving occurred between 0000 and $0600 \mathrm{~h}$. As a result, the 224 data points included values from 19, 33, and 71 Holsteins that calved within 6,12 , and $24 \mathrm{~h}$, respectively. We ran binomial logistic regression using GEE separately to predict parturition within $6 \mathrm{~h}$ (19 samples from cows that had calved within 6 h, 205 samples from cows that had not calved), $12 \mathrm{~h}$ (33 samples from cows that calved within $12 \mathrm{~h}, 191$ samples from cows that had not calved), and $24 \mathrm{~h}$ (71 samples from cows that calved within $24 \mathrm{~h}, 153$ samples from cows that had not calved). Parity (primiparous or multiparous) was not a significant factor when plasma [prog] was evaluated as a predictor for parturition within $6 \mathrm{~h}(P=0.99), 12 \mathrm{~h}(P=0.22)$, or $24 \mathrm{~h}(P=0.21)$.

Plasma [prog] was a significant predictor of parturition within 6,12 , and $24 \mathrm{~h}(P<0.001)$; the numerically highest AUC was for predicting calving within 
$24 \mathrm{~h}$ (Table 1$)$. The probability $(P)$ of predicting calving within $6 \mathrm{~h}$ from plasma $[\mathrm{prog}]$ in $\mathrm{ng} / \mathrm{mL}$ could be calculated using the following GEE: $P=1 /[1+$ $\left.e^{-(-1.13 \times[\mathrm{prog}]+1.77)}\right]$. The optimal cut-point for predicting parturition within $6 \mathrm{~h}$ was plasma $[\mathrm{prog}]<3.90 \mathrm{ng} /$ $\mathrm{mL}(\mathrm{AUC}=0.91)$, equivalent to $P=0.067$ (Figure 2). The probability for predicting calving within $12 \mathrm{~h}$ from plasma [prog] could be calculated using the following GEE: $P=1 /\left[1+e^{-(-1.22 \times[\text { prog }]+2.97)}\right]$. The optimal cut-point for predicting parturition within $12 \mathrm{~h}$ was plasma [prog] $<3.52 \mathrm{ng} / \mathrm{mL}(\mathrm{AUC}=0.93)$, equivalent to $P=0.21$. For comparison, the GEE equation for predicting calving within $24 \mathrm{~h}$ from plasma [prog] was $P=1 /\left[1+e^{-(-1.50 \times[\mathrm{prog}]+6.27)}\right]$. The optimal cut-point for predicting parturition within $24 \mathrm{~h}$ was plasma [prog] $<4.63 \mathrm{ng} / \mathrm{mL}(\mathrm{AUC}=0.96)$, equivalent to $P=0.34$.

\section{Plasma Cortisol Concentration-Time Relationship}

Mixed-model analysis indicated that time $(P<$ $0.001)$ and parity $(P=0.0014)$ had significant main effects on plasma [cortisol], but the interaction of parity and time was not significant (Figure 3). Compared with d 2 antepartum, plasma [cortisol] was increased in primiparous and multiparous Holsteins at 24 and $12 \mathrm{~h}$ before calving, as well as at calving. Blood and plasma glucose concentrations during the $24 \mathrm{~h}$ period spanning parturition were positively associated with plasma [cortisol] $(\mathrm{r}=0.51, P<0.001 ; \mathrm{r}=0.62, P<0.001 ; \mathrm{n}=80)$.

\section{Blood Glucose Concentration-Time Relationship}

We conducted separate analyses for the $[\mathrm{gluc}]_{\mathrm{p}}$-time relationship for primiparous and multiparous Holsteins (see the following section for rationale). Mixed-model segmented linear regression for primiparous Holsteins indicated that $[\text { gluc }]_{\mathrm{b}}$ remained constant at $65 \mathrm{mg} / \mathrm{dL}$ (95\% CI 62 to 69$)$ until -1.08 d $(95 \%$ CI -1.30 to -0.85 ) or $26 \mathrm{~h}$ before parturition (Figure 4). The [gluc] $\mathrm{b}$ increased in a linear manner after this time $t$ in days, such that: $[\text { gluc }]_{\mathrm{b}}=65+30 \times(\mathrm{t}+1.08)$. The $95 \%$ CI for the slope coefficient $\left(b_{1}\right)$ was 19 to 40 . For com-

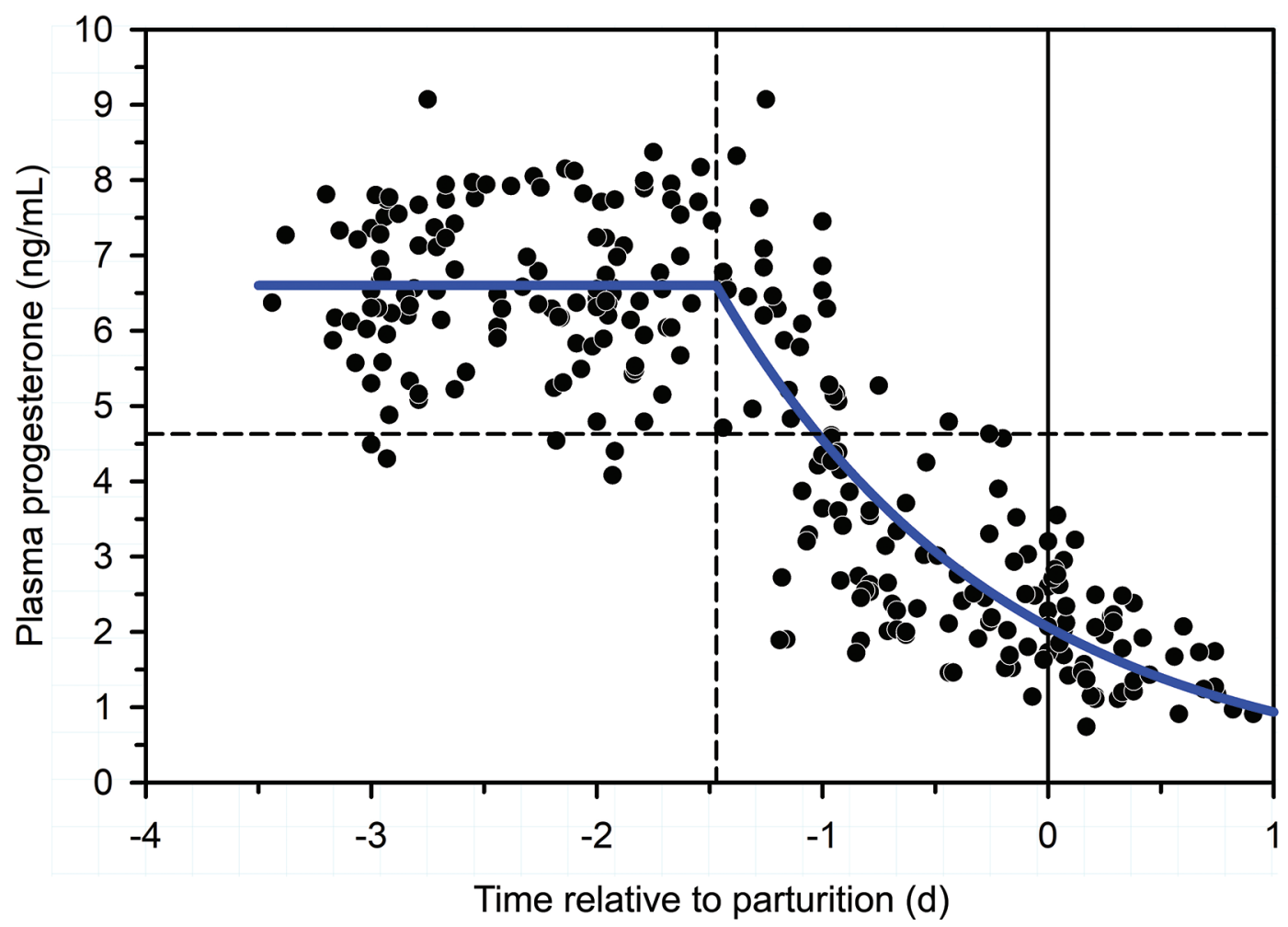

Figure 1. Scatterplot of the relationship between plasma progesterone concentration ([prog]) and time relative to parturition in 71 lategestation primiparous and multiparous Holstein cows (total of 271 data points, including 47 from the first $24 \mathrm{~h}$ after calving). The vertical solid line indicates the time of calving. Segmented nonlinear regression indicated that plasma [prog] was constant until $35 \mathrm{~h}$ before calving (vertical dashed line), after which time plasma [prog] decreased in an exponential manner. The horizontal dashed line indicates the optimal cut-point $(<4.63 \mathrm{ng} / \mathrm{mL})$ for plasma [prog] to predict calving within $24 \mathrm{~h}$. 
Hiew et al.: PREDICTING PARTURITION IN DAIRY COWS

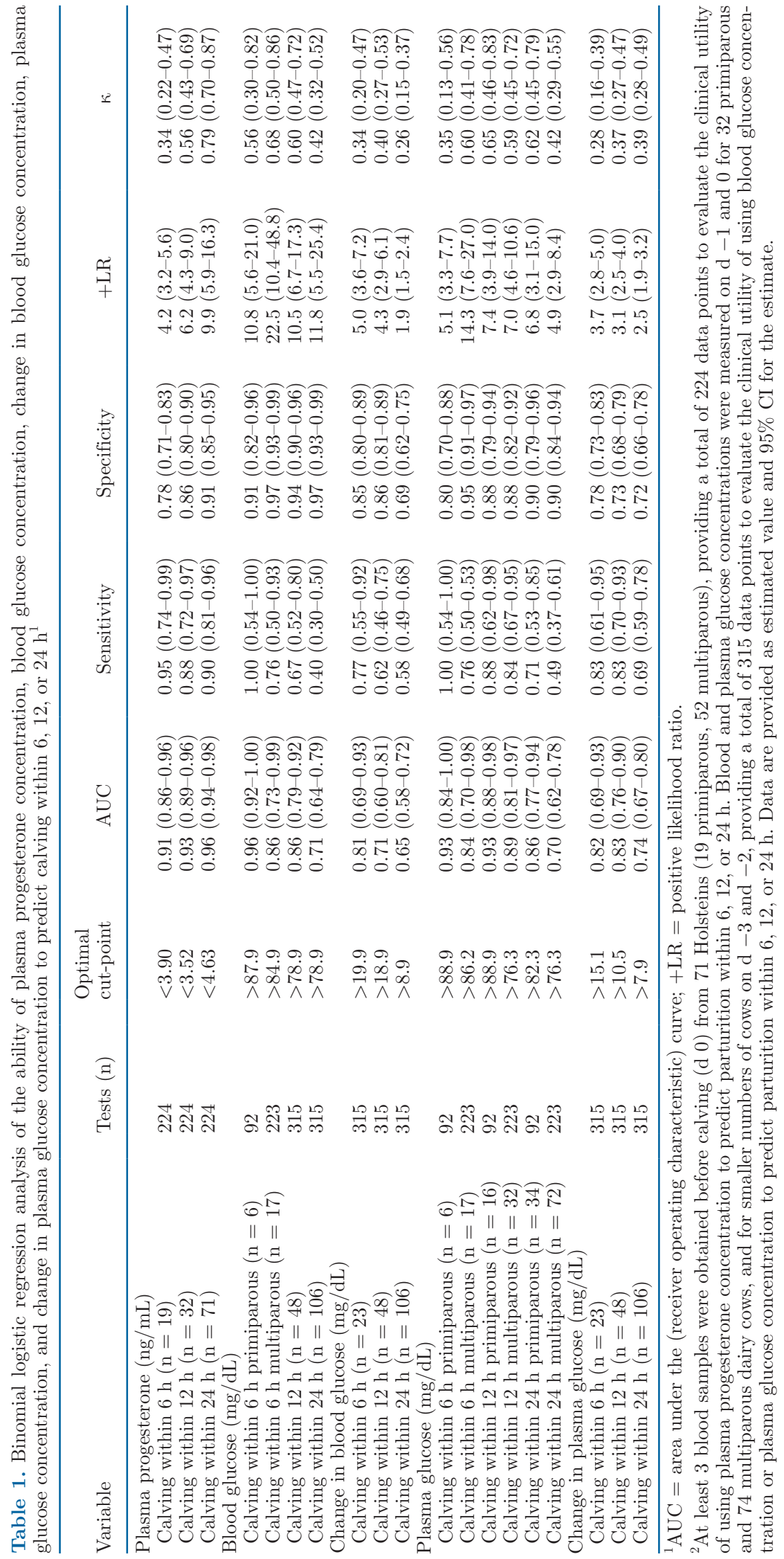




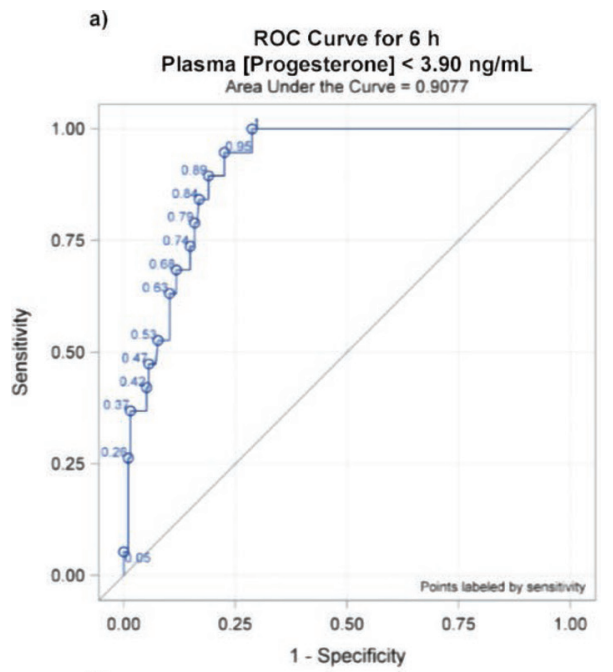

b)

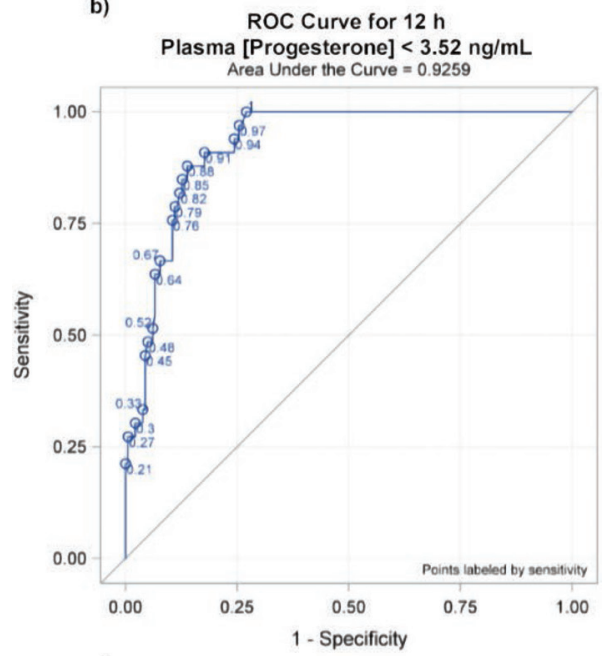

c)

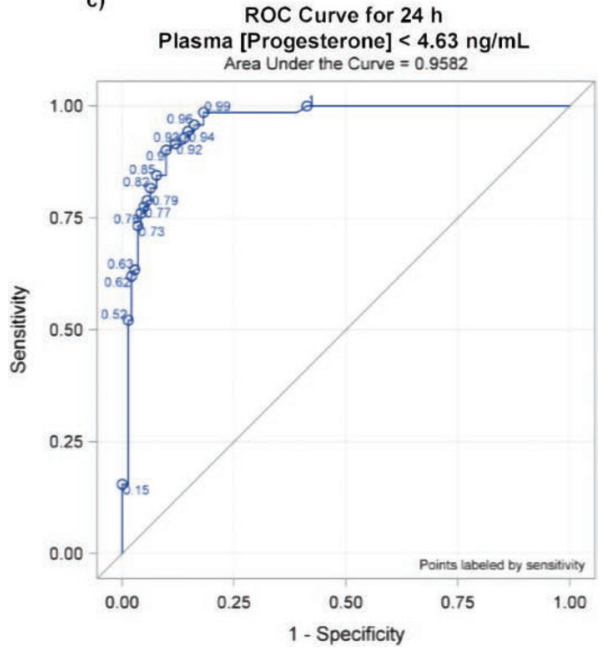

Figure 2. Receiver operating characteristic (ROC) curves for plasma progesterone concentration $([\operatorname{prog}])$ as a predictor of parturition within $6 \mathrm{~h}$ (a), $12 \mathrm{~h}$ (b), or $24 \mathrm{~h}$ (c) in 71 late-gestation primiparous and multiparous Holstein cows. The diagonal thin line is the line of chance (no predictive ability). The optimal cut-points for predicting parturition within 6,12 , or $24 \mathrm{~h}$ were plasma [prog] $<3.90,3.52$, and $4.63 \mathrm{ng} / \mathrm{mL}$, respectively. parison, mixed-model segmented linear regression for multiparous Holsteins indicated that $[\text { gluc }]_{\mathrm{b}}$ remained constant at $60 \mathrm{mg} / \mathrm{dL}(95 \%$ CI 59 to 61$)$ until -0.80 d $(95 \%$ CI -0.90 to -0.70$)$ or $19 \mathrm{~h}$ before parturition. The $[\text { gluc }]_{\mathrm{b}}$ increased in a linear manner after this time $\mathrm{t}$ in days, such that $[\text { gluc }]_{\mathrm{b}}=60+40 \times(\mathrm{t}+0.80)$. The $95 \% \mathrm{CI}$ for the slope coefficient $\left(\mathrm{b}_{1}\right)$ was 32 to 49.

\section{Blood Glucose Concentration: Prediction of Calving}

At least 1 blood sample was available before calving (d 0) for 106 Holsteins (34 primiparous, 72 multiparous), providing a total of 315 data points to evaluate the clinical utility of $\left[\right.$ gluc $_{\mathrm{b}}$ for predicting parturition within 6,12 , or $24 \mathrm{~h}$. Twenty-three Holsteins calved within $6 \mathrm{~h}$ (6 primiparous, 17 multiparous), 48 cows calved within $12 \mathrm{~h}$ (16 primiparous, 32 multiparous), and 106 cows calved within $24 \mathrm{~h}$ (34 primiparous, 72 multiparous).

Blood glucose concentration was a significant predictor of parturition within 6,12 , and $24 \mathrm{~h}(P<0.001$; Table 1). Parity (primiparous or multiparous) was a significant factor when $[\mathrm{gluc}]_{\mathrm{b}}$ was evaluated as a predictor for parturition within $6 \mathrm{~h}(P=0.031)$, but not when evaluated as a predictor within $12 \mathrm{~h}(P=0.18)$ or $24 \mathrm{~h}(P=0.33)$. Therefore, we ran binomial logistic regression using GEE separately for primiparous and multiparous Holsteins only to predict parturition within $6 \mathrm{~h}$.

The GEE equation for predicting calving within 6 $\mathrm{h}$ for primiparous cows by measuring $[\text { gluc }]_{\mathrm{b}}$ in $\mathrm{mg} / \mathrm{dL}$ was $P=1 /\left[1+e^{-(0.131 \times[\text { gluc]b-13.76) }}\right]$. The optimal cutpoint for predicting parturition within $6 \mathrm{~h}$ was [gluc] b $>87.9 \mathrm{mg} / \mathrm{dL}(\mathrm{AUC}=0.96)$, equivalent to an estimated probability of 0.10 (Figure 5). For comparison, the GEE equation for predicting calving within $6 \mathrm{~h}$ for multiparous cows by measuring $[\mathrm{gluc}]_{\mathrm{b}}$ in $\mathrm{mg} / \mathrm{dL}$ was $P=1 /\left[1+e^{-(0.108 \times[\text { gluc] }-10.42)}\right]$. The optimal cut-point for predicting parturition within $6 \mathrm{~h}$ was $[\text { gluc }]_{\mathrm{b}}>84.9$ $\mathrm{mg} / \mathrm{dL}(\mathrm{AUC}=0.86)$, equivalent to an estimated probability of 0.22 .

The GEE equation for predicting calving within $12 \mathrm{~h}$ from $[\text { gluc }]_{\mathrm{b}}($ in $\mathrm{mg} / \mathrm{dL})$ was $P=1 /\left[1+e^{-(0.081 \times[\text { gluc }] \mathrm{b}-7.87)}\right]$. The optimal cut-point for predicting parturition within $12 \mathrm{~h}$ was gluc $_{\mathrm{b}}>78.9 \mathrm{mg} / \mathrm{dL}(\mathrm{AUC}=0.86)$, equivalent to an estimated probability of 0.19 (Figure 5). The GEE equation for predicting calving within $24 \mathrm{~h}$ from [gluc $]_{\mathrm{b}}$ was $P=1 /\left[1+e^{-(0.052 \times[\text { gluc }] \mathrm{b}-4.16)}\right]$. The optimal cut-point for predicting parturition within $24 \mathrm{~h}$ was gluc $_{\mathrm{b}}>78.9 \mathrm{mg} / \mathrm{dL}(\mathrm{AUC}=0.71)$, equivalent to an estimated probability of 0.49 .

We calculated the change in $\left[\right.$ gluc $_{b}$ from the previous days' value and examined the increase in $[\text { gluc }]_{b}$ over the previous $24 \mathrm{~h}$ as a predictor of prediction (Table 1 ). 


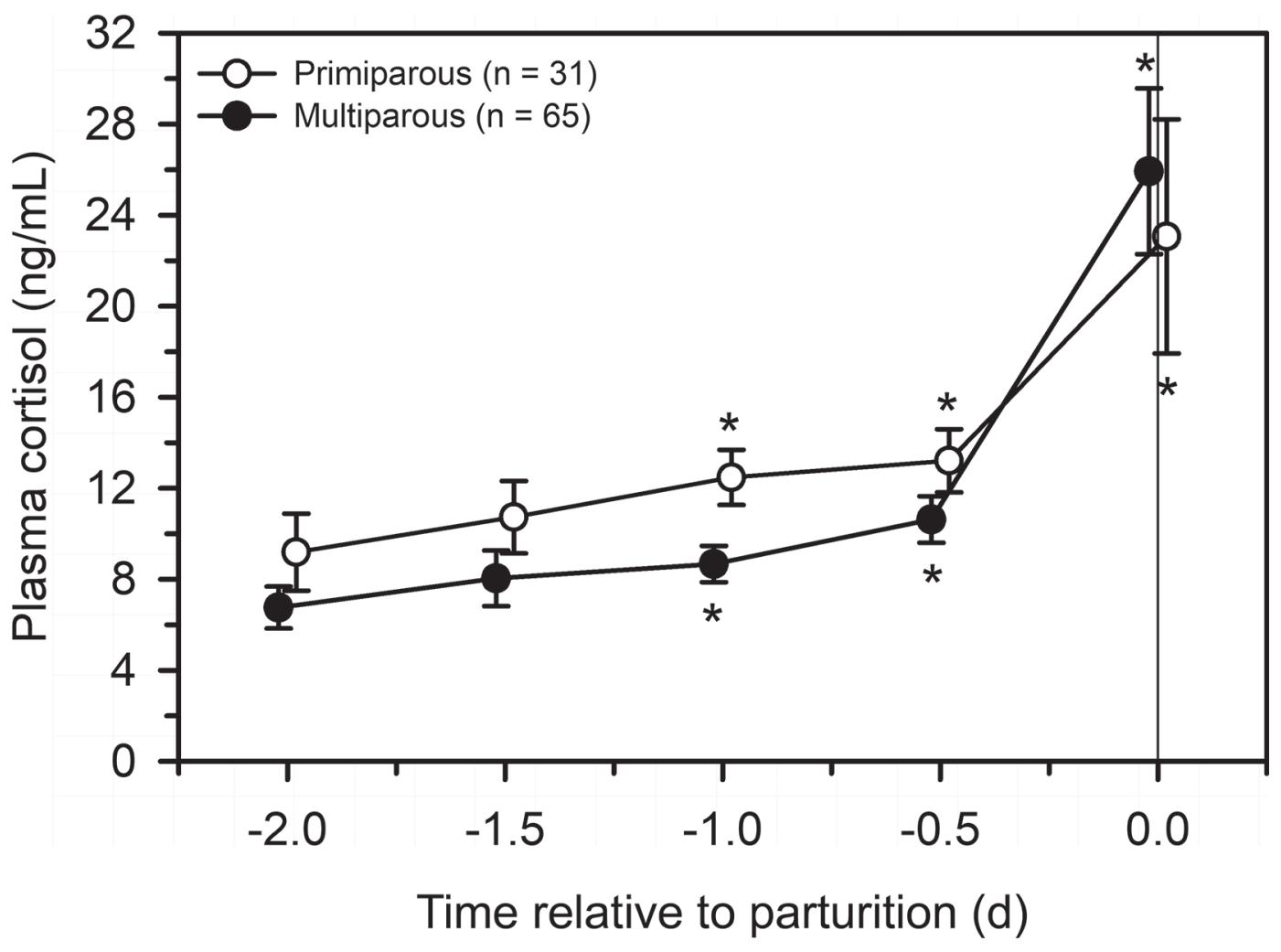

Figure 3. Antepartum changes in plasma cortisol concentration in 31 primiparous and 65 multiparous late-gestation Holstein cows over the last $2 \mathrm{~d}$ before calving. Data are offset slightly to improve readability and presented as LSM $\pm \mathrm{SE}$. The vertical solid line at time $=0 \mathrm{~d}$ represents the time of calving. ${ }^{*} P<0.05$ compared with time $=-2 \mathrm{~d}$ within each group.

In all cases, change in $[\text { gluc }]_{\mathrm{b}}$ was a poorer predictor of parturition than actual $[\text { gluc }]_{b}$.

\section{Plasma Glucose Concentration-Time Relationship}

We conducted separate analyses for the $[\mathrm{gluc}]_{\mathrm{p}}-$ time relationship for primiparous and multiparous Holstein cows. Mixed-model segmented linear regression for primiparous Holstein cows indicated that [gluc $]_{\mathrm{p}}$ remained constant at $74 \mathrm{mg} / \mathrm{dL}(95 \%$ CI 71 to 77$)$ until -1.20 d (95\% CI -1.40 to -1.00$)$, or $29 \mathrm{~h}$ before parturition (Figure 6). The gluc $_{\mathrm{p}}$ increased in a linear manner after this time $\mathrm{t}$ in days, such that gluc $_{\mathrm{p}}=74+28$ $\times(t+1.20)$. The $95 \%$ CI for the slope coefficient $\left(b_{1}\right)$ was 20 to 35. For comparison, mixed-model segmented linear regression for multiparous Holsteins indicated that $[\text { gluc }]_{\mathrm{p}}$ remained constant at $68 \mathrm{mg} / \mathrm{dL}(95 \%$ CI 66 to 70$)$ until -0.89 d ( $95 \%$ CI -1.04 to -0.74$)$, or 21 $\mathrm{h}$ before parturition. The $[\mathrm{gluc}]_{\mathrm{p}}$ increased in a linear manner after this time $t$ in days, such that $[\text { gluc }]_{\mathrm{p}}=68$ $+31 \times(\mathrm{t}+0.89)$. The $95 \%$ CI for the slope coefficient $\left(b_{1}\right)$ was 22 to 39 .

\section{Plasma Glucose Concentration: Prediction of Calving}

At least 1 plasma sample was available before calving (d 0) for 106 Holsteins (34 primiparous, 72 multiparous), providing a total of 315 data points to evaluate the clinical utility of $[\mathrm{gluc}]_{\mathrm{p}}$ for predicting parturition within 6,12 , or 24 h. Plasma glucose concentration was a significant predictor of parturition within 6,12 , and $24 \mathrm{~h}(P<0.001$; Table 1$)$, and primiparous and multiparous Holstein cows had the numerically highest AUC for predicting calving within $12 \mathrm{~h}$ (Table 1). Parity (primiparous or multiparous) was also a significant predictive factor for parturition within $6 \mathrm{~h}(P$ $=0.0065), 12 \mathrm{~h}(P=0.0045)$, or $24 \mathrm{~h}(P=0.0045)$. Therefore, we performed separate analyses to evaluate the ability of [gluc $]_{\mathrm{p}}$ to predict calving within 6,12 , and $24 \mathrm{~h}$ in primiparous or multiparous cows.

The GEE equation for predicting calving in primiparous cattle within $6 \mathrm{~h}$ using $[\mathrm{gluc}]_{\mathrm{p}}$ in $\mathrm{mg} / \mathrm{dL}$ was $P=$ $1 /\left[1+e^{-(0.133 \times[\text { gluc }] p-14.87)}\right]$. The optimal cut-point for predicting parturition within $6 \mathrm{~h}$ in primiparous cattle 
was $[\text { gluc }]_{\mathrm{p}}>88.9 \mathrm{mg} / \mathrm{dL}(\mathrm{AUC}=0.93)$, equivalent to $P=0.045$ (Figure 7). For comparison, the GEE equation for predicting calving in multiparous cows within 6 h using [gluc $]_{\mathrm{p}}$ was $P=1 /\left[1+e^{-(0.121 \times[\text { gluc }] \mathrm{p}-12.09)}\right]$. The optimal cut-point for predicting parturition within $6 \mathrm{~h}$ in multiparous cows was [gluc $_{\mathrm{p}}>86.2 \mathrm{mg} / \mathrm{dL}(\mathrm{AUC}=$ 0.84 ), equivalent to $P=0.16$.

The GEE equation for predicting calving in primiparous cows within $12 \mathrm{~h}$ using [gluc $_{\mathrm{p}}$ was $P=1 /[1+$ $\left.e^{-(0.152 \times[\text { gluc }] \mathrm{p}-14.71)}\right]$. The optimal cut-point for predicting parturition within $12 \mathrm{~h}$ in primiparous cows was gluc $_{\mathrm{p}}>88.9 \mathrm{mg} / \mathrm{dL}(\mathrm{AUC}=0.93)$, equivalent to $P=$ 0.23 (Figure 7). For comparison, the GEE equation for predicting calving in multiparous cows within $12 \mathrm{~h}$ was $P=1 /\left[1+e^{-(0.157 \times[\text { gluc }] p-13.79)}\right]$. The optimal cut-point for predicting parturition within $12 \mathrm{~h}$ in multiparous cows was $[\text { gluc }]_{\mathrm{p}}>76.3 \mathrm{mg} / \mathrm{dL}(\mathrm{AUC}=0.89)$, equivalent to $P=0.14$.

The GEE equation for predicting calving in primiparous cows within $24 \mathrm{~h}$ using measured [gluc $]_{\mathrm{p}}$ in $\mathrm{mg} /$ $\mathrm{dL}$ was $P=1 /\left[1+e^{-(0.149 \times[\text { gluc]p }-12.59)}\right]$. The optimal cut-point for predicting parturition within $24 \mathrm{~h}$ in pri- miparous cows was $[\text { gluc }]_{\mathrm{p}}>82.3 \mathrm{mg} / \mathrm{dL}(\mathrm{AUC}=0.86)$, equivalent to $P=0.42$ (Figure 7). For comparison, the GEE equation for predicting calving in multiparous cattle within $24 \mathrm{~h}$ using [gluc $]_{\mathrm{p}}$ was $P=1 /[1+$ $\left.e^{-(0.088 \times[\text { gluc]p }-7.10)}\right]$. The optimal cut-point for predicting parturition within $24 \mathrm{~h}$ in multiparous cows was $[\text { gluc }]_{\mathrm{p}}>76.3 \mathrm{mg} / \mathrm{dL}(\mathrm{AUC}=0.70)$, equivalent to $P=$ 0.40 .

We calculated the change in $[\mathrm{gluc}]_{\mathrm{p}}$ from the previous day's value and examined the increase in $[\mathrm{gluc}]_{\mathrm{p}}$ over the previous $24 \mathrm{~h}$ as a predictor of prediction (Table 1 ). In all cases, change in $[\mathrm{gluc}]_{\mathrm{p}}$ was a poorer predictor of parturition than actual $[\text { gluc }]_{\mathrm{p}}$.

\section{DISCUSSION}

Most studies identifying statistically significant predictors of parturition in cattle have evaluated individual factors, and very few have specifically evaluated differences that may occur between primiparous and multiparous dairy cattle. Although the majority of studied variables are statistically significant predictors of par-

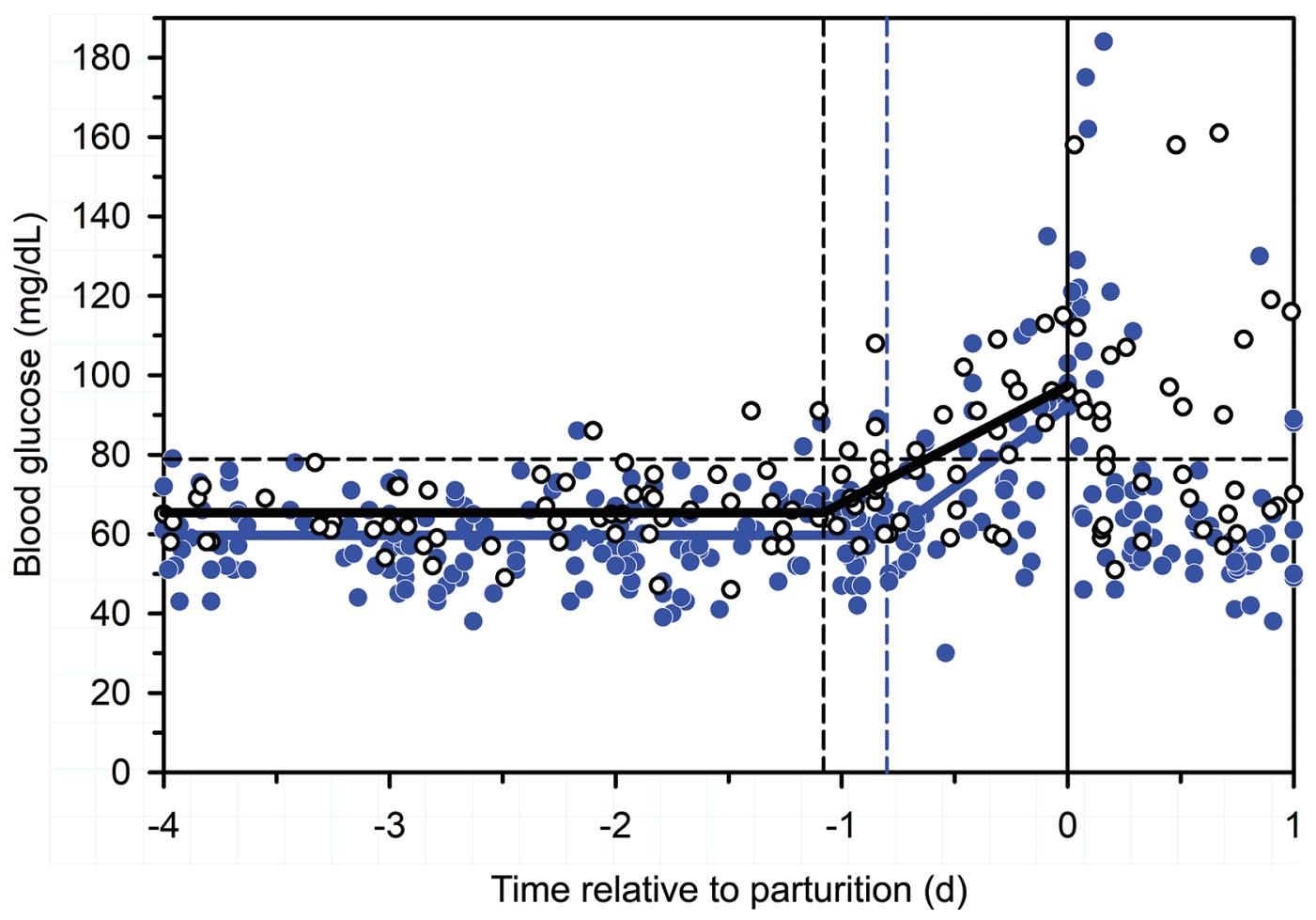

Figure 4. Scatterplot of the relationship between blood glucose concentration ([gluc $]_{\mathrm{b}}$ ) for primiparous (open circles, $\left.\mathrm{n}=34\right)$ and multiparous (filled blue circles, $\mathrm{n}=72$ ) Holstein cows and time relative to parturition (total of 424 data points, including 109 from the first $24 \mathrm{~h}$ after calving). The vertical solid line indicates the time of calving. Segmented linear regression indicated that [gluc $]_{\mathrm{b}}$ was constant until $26 \mathrm{~h}$ before calving for primiparous Holstein cows (black vertical dashed line) and $19 \mathrm{~h}$ before calving for multiparous Holstein cows (blue vertical dashed line), after which time gluc $_{\mathrm{b}}$ increased in a linear manner until calving. The horizontal dashed bar indicates the optimal cut-point (>79 mg/ $\mathrm{dL}$ ) for [gluc $]_{\mathrm{b}}$ to predict calving within $12 \mathrm{~h}$ for primiparous and multiparous Holstein cows. 
a)

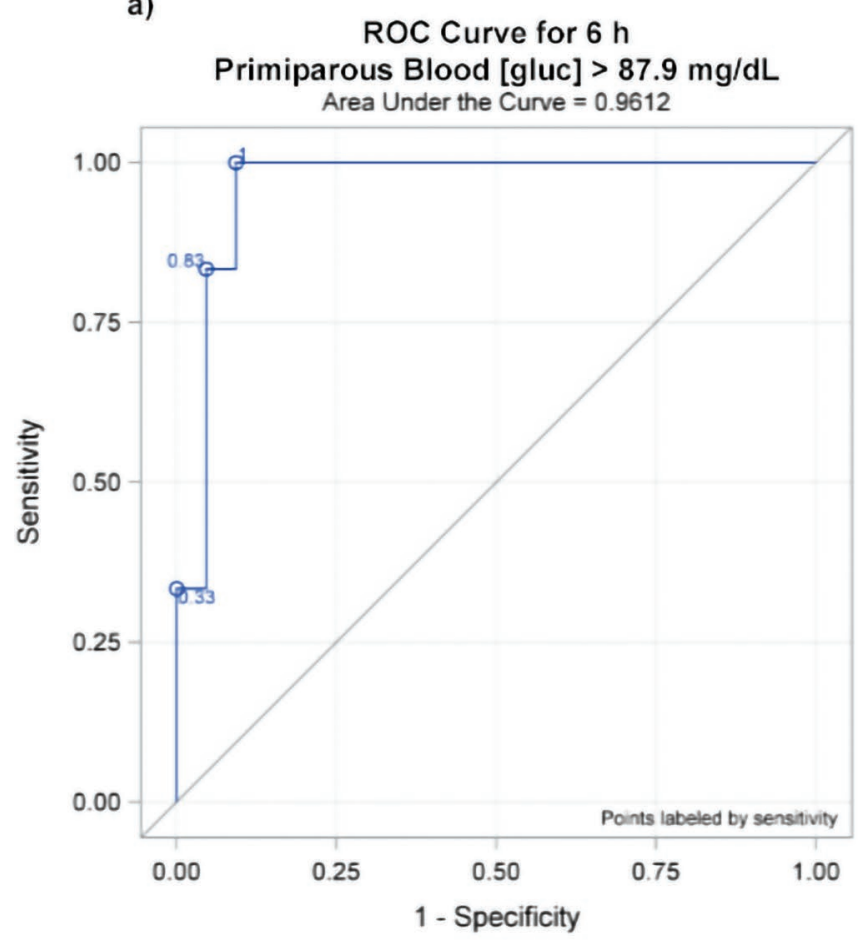

c)

ROC Curve for $12 \mathrm{~h}$

Blood [gluc] $>78.9 \mathrm{mg} / \mathrm{dL}$

Area Under the Curve $=0.8558$

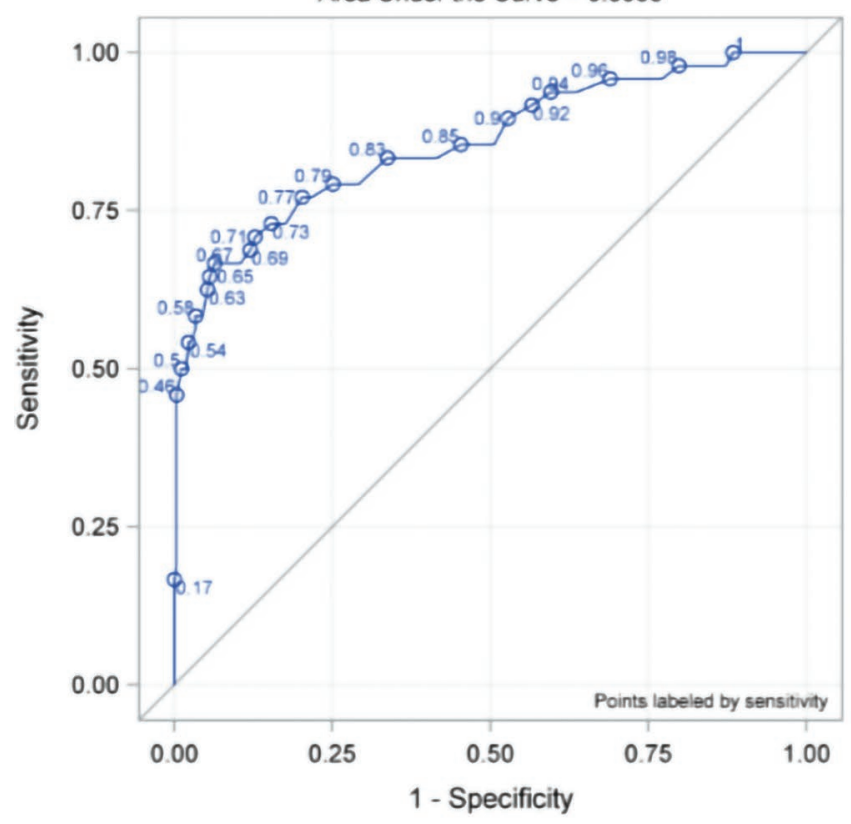

b)

ROC Curve for $6 \mathrm{~h}$ Multiparous Blood [gluc] $>84.9 \mathrm{mg} / \mathrm{dL}$ Area Under the Curve $=0.8602$

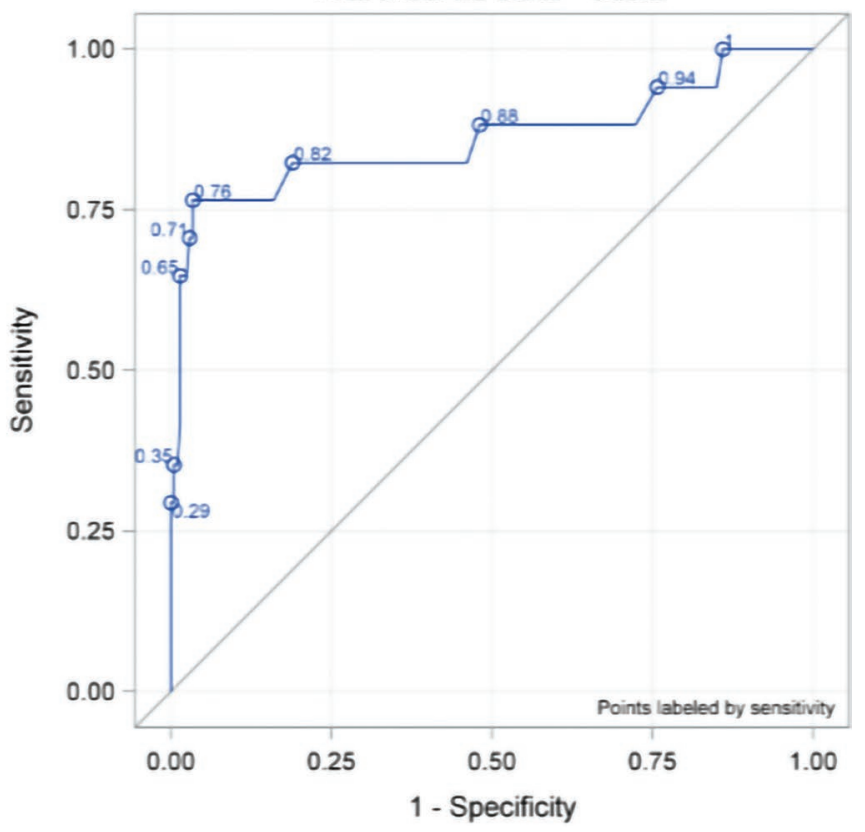

d)

ROC Curve for $24 \mathrm{~h}$ Blood [gluc] > $78.9 \mathrm{mg} / \mathrm{dL}$ Area Under the Curve $=0.7075$

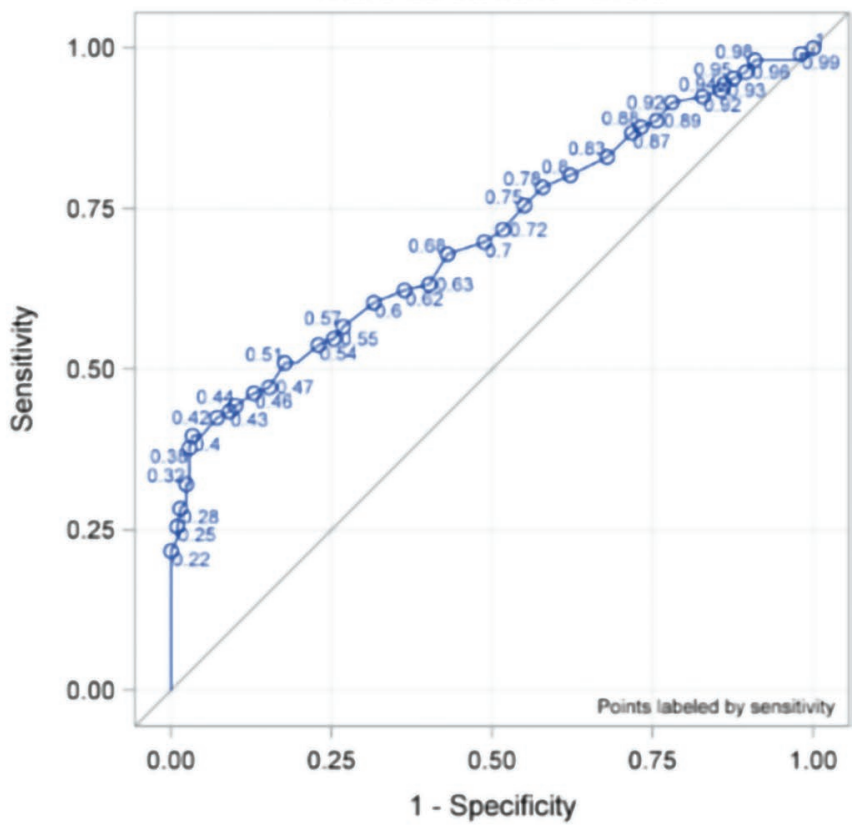

Figure 5. Receiver operating characteristic (ROC) curves for blood glucose concentration ([gluc $\left.]_{\mathrm{b}}\right)$ as a predictor of parturition within $6 \mathrm{~h}$ for primiparous Holstein cows (a), $6 \mathrm{~h}$ for multiparous Holstein cows (b), $12 \mathrm{~h}$ (c), or $24 \mathrm{~h}$ (d). The diagonal thin line is the line of chance (no predictive ability). The optimal cut-points for predicting parturition within $6 \mathrm{~h}$ for primiparous or multiparous cows were $[\mathrm{gluc}]_{\mathrm{b}}>87.9 \mathrm{mg} / \mathrm{dL}$ [area under the curve $(\mathrm{AUC})=0.86]$ or $>84.9 \mathrm{mg} / \mathrm{dL}(\mathrm{AUC}=0.96)$, respectively. For comparison, the optimal cut-point for predicting calving within $12 \mathrm{~h}$ was $[\mathrm{gluc}]_{\mathrm{b}}>78.9 \mathrm{mg} / \mathrm{dL}(\mathrm{AUC}=0.86$ ), equivalent to an estimated probability of 0.19 . The optimal cut-point for predicting parturition within $24 \mathrm{~h}$ was $[\mathrm{gluc}]_{\mathrm{b}}>78.9 \mathrm{mg} / \mathrm{dL}(\mathrm{AUC}=0.71)$, equivalent to an estimated probability of 0.49. 


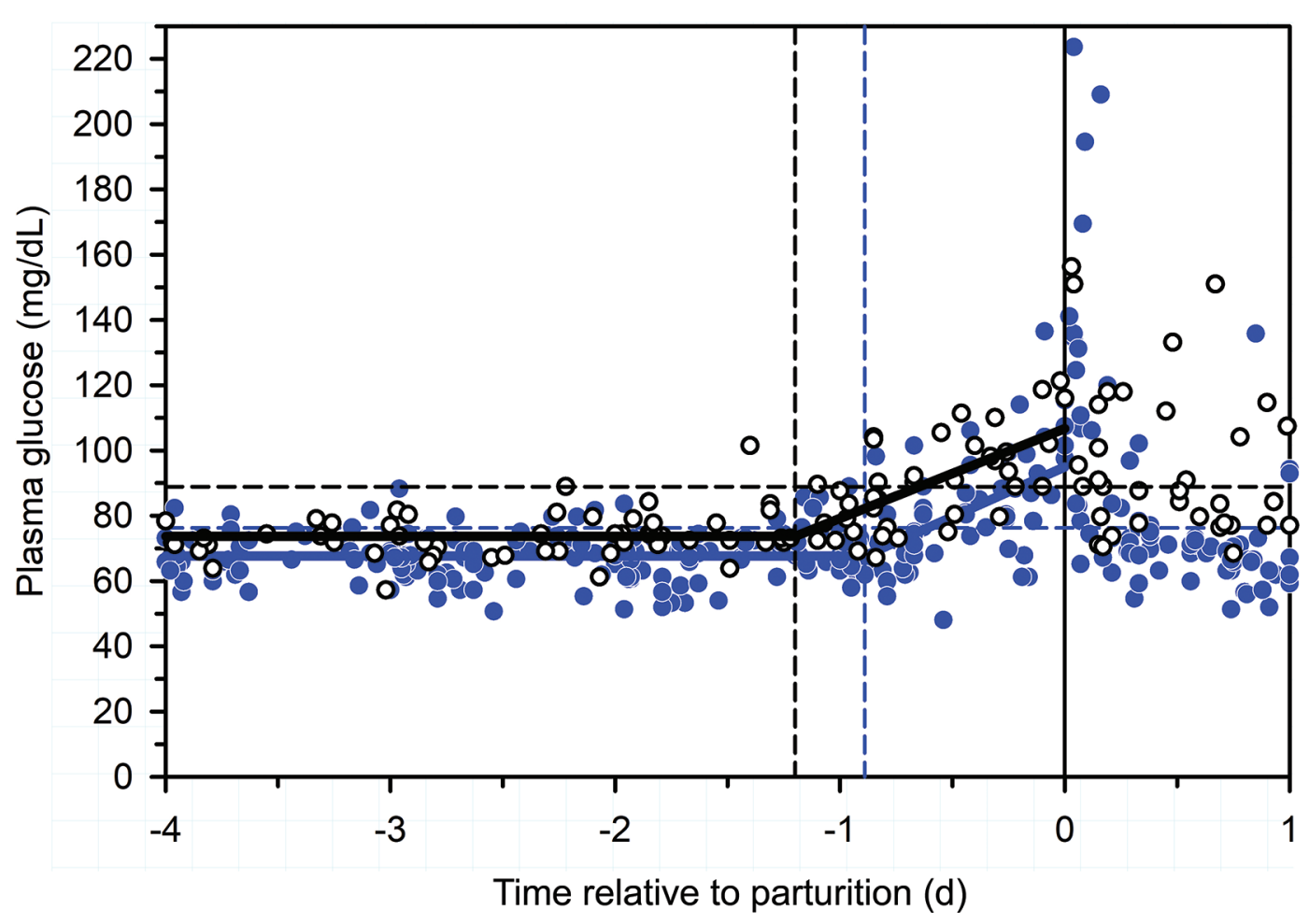

Figure 6. Scatterplot of the relationship between plasma glucose concentration ([gluc $]_{\mathrm{p}}$ ) for primiparous (open circles, $\mathrm{n}=34$ ) and multiparous (filled blue circles, $\mathrm{n}=72$ ) Holstein cows and time relative to parturition (total of 414 data points, including 99 from the first $24 \mathrm{~h}$ after calving). The vertical solid line indicates the time of calving. Segmented linear regression indicated that [gluc $]_{\mathrm{p}}$ was constant until $29 \mathrm{~h}$ before calving for primiparous Holstein cows (black vertical dashed line) and $21 \mathrm{~h}$ before calving for multiparous Holstein cows (blue vertical dashed line), after which time $[\mathrm{gluc}]_{\mathrm{p}}$ increased in a linear manner until calving. The horizontal dashed bar indicates the optimal cut-points (>89 and $>76 \mathrm{mg} / \mathrm{dL}$ ) for $[\mathrm{gluc}]_{\mathrm{p}}$ to predict calving within $12 \mathrm{~h}$ for primiparous and multiparous Holstein cows, respectively.

turition, very few-with the possible exception of the ventral tail base surface temperature (Koyama et al., 2018), frequency of tail-raising (Miedema et al., 2011), degree of cervical dilatation (Taverne et al., 2002), and the presence of bloody vaginal discharge (Lange et al., 2017) or abdominal contractions (tensing of the ventral portion of the abdomen due to the fetal feet contacting the vaginal wall; Gillette and Holm, 1963; Berglund et al., 1987; Schuenemann et al., 2011; Barrier et al., 2012; Lange et al., 2017) - are sufficiently accurate predictors of parturition to be clinically useful. In this study, we characterized the clinical utility of plasma [prog] as the reference method and $[\mathrm{gluc}]_{\mathrm{b}}$ or $[\mathrm{gluc}]_{\mathrm{p}}$ as cow-side or on-farm tests for predicting calving within 6,12 , and $24 \mathrm{~h}$ in Holstein heifers and cows. We assumed that test Se and Sp were of equal importance, and on this basis, AUC, $+\mathrm{LR}$, and the $\kappa$ coefficient provided the best indices of overall test performance for the methods under evaluation. Our first major finding was that plasma [prog] starts to decrease $35 \mathrm{~h}$ before expulsion of the calf. Our second major finding was that plasma [prog] $<4.6 \mathrm{ng} / \mathrm{mL}$ was an excellent predictor of parturition within $24 \mathrm{~h}$ in primiparous and multiparous Holsteins, based on $\mathrm{AUC}=0.96,+\mathrm{LR}=9.9$, and $\kappa=0.78$, and that plasma [prog] was more accurate when used to predict parturition within $24 \mathrm{~h}$, than within 6 or $12 \mathrm{~h}$. Our third major finding was that $[\mathrm{gluc}]_{\mathrm{b}}$ and $[\mathrm{gluc}]_{\mathrm{p}}$ are clinically useful tests for predicting parturition within 6 or $12 \mathrm{~h}$, particularly in heifers.

Parturition in cattle is a process initiated by the fetus and requires progressive maturation and activation of the fetal hypothalamus-pituitary-adrenal (HPA) axis as parturition approaches (Wood, 1999; Schuler et al., 2018). Activation of the fetal HPA axis results in secretion of corticotrophin releasing factor by the fetal hypothalamus. Adrenocorticotrophic hormone is then released from the fetal anterior pituitary gland, which in turn causes the release of cortisol from the cortical region of the fetal adrenal glands (Wood, 1999). The result is a rapid increase in fetal plasma [cortisol] at the time of parturition to a mean of $74 \mathrm{ng} / \mathrm{mL}$ (Hunter et al., 1977); however, it is important to note that minimal amounts of fetal cortisol cross over into the maternal circulation in ruminants (Dixon et al., 1970). Fetal hypercortisolemia appears to initiate the decline in maternal plasma [prog] in cattle through an uniden- 

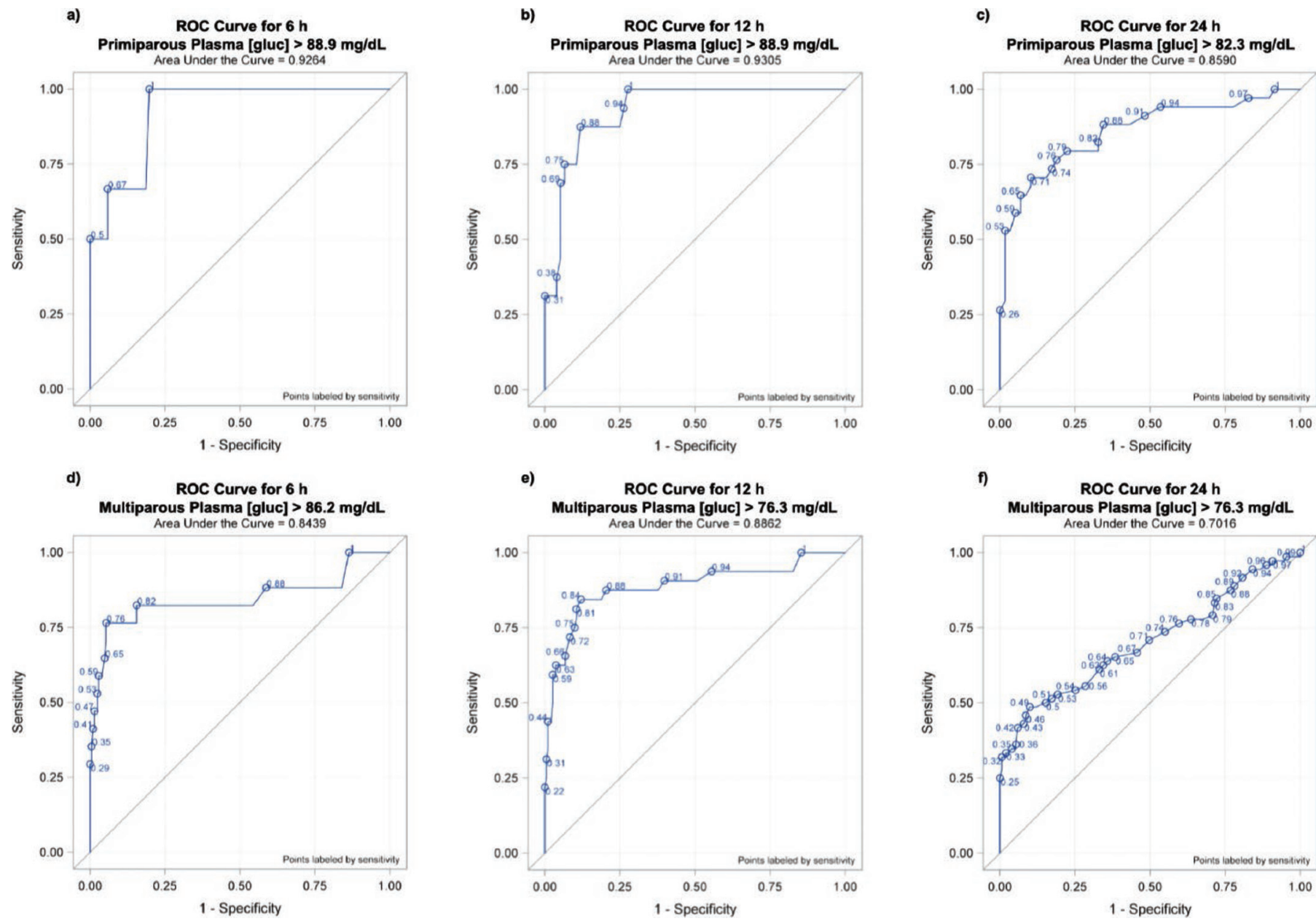

Figure 7. Receiver operating characteristic (ROC) curves for plasma glucose concentration ([gluc $]_{\mathrm{p}}$ ) as a predictor of parturition within 6 , 12, and $24 \mathrm{~h}$ for primiparous Holstein cows ( $\mathrm{a}, \mathrm{b}, \mathrm{c})$ and multiparous Holstein cows ( $\mathrm{d}, \mathrm{e}, \mathrm{f})$. The diagonal thin line is the line of chance (no predictive ability). The optimal cut-points for predicting parturition in primiparous cattle within $6 \mathrm{~h}, 12 \mathrm{~h}$, and $24 \mathrm{~h}$ were $[\text { gluc }]_{\mathrm{p}}>88.9,88.9$, and $82.3 \mathrm{mg} / \mathrm{dL}$, respectively. The optimal cut-points for predicting parturition in multiparous cattle within 6,12 , and $24 \mathrm{~h} \mathrm{were}[\mathrm{gluc}]_{\mathrm{p}}>86.2$, $>76.3$, and $>76.3 \mathrm{mg} / \mathrm{dL}$, respectively.

tified pathway that most likely involves the production of luteolytic prostaglandins by the cotyledons (Schuler et al., 2018). Whatever the mechanism, luteal regression in cattle provides the major contribution to the decrease in plasma [prog] before parturition (Shenavai et al., 2012; Schuler et al., 2018; Conley et al., 2019). Determination of the exact prepartal time point when luteolysis is initiated - thereby identifying the time when plasma [prog] starts to decline - is required to determine the nature and origin of the prepartal luteolytic signal in cattle (Schuler et al., 2018). Application of segmented nonlinear regression in this study provided a novel method for objectively determining that plasma [prog] starts to decrease 35 h (95\% CI 33 to 37 h) before fetal expulsion. Our finding was consistent with previous studies that binned late-gestation plasma [prog] data into $12 \mathrm{~h}$ (Birgel et al., 1994) or $24 \mathrm{~h}$ (Matsas et al., 1992) time intervals, and was consistent with studies demonstrating that parenteral administration of dexamethasone or prostaglandin $\mathrm{F} 2 \alpha$ in late gestation results in calving approximately $41 \mathrm{~h}$ later (Shenavai et al., 2012). Our finding suggests that the prepartal luteolytic signal in cattle must be present at least $33 \mathrm{~h}$ before fetal expulsion.

The AUC (0.96) for plasma [prog] $<4.6 \mathrm{ng} / \mathrm{mL}$ to predict calving within $24 \mathrm{~h}$ appeared to be the highest AUC value obtained for predicting calving. We anticipated this result, because there is broad consensus that a decrease in maternal plasma [prog] is the initiating maternal signal for parturition in cattle (Schuler et al., 2018). The ELISA used in this study to measure plasma [prog] had a relatively high $\mathrm{CV}$, and we made 
duplicate measurements based on this variability. It is possible that the use of a more precise progesterone assay or triplicate measurements may have increased the overall test performance of plasma [prog] as a predictor of parturition. It needs to be emphasized that the accurate measurement of plasma [prog] concentrations in cattle is challenging, particularly when using antibody-based techniques, because of the presence of cross-reactivity (Hankele et al., 2020). Consequently, the plasma [prog] cut-points identified in our study are assay-specific. A 1999 test evaluation study demonstrated that the ELISA used in this study was linear ( $\mathrm{r}$ $=0.998)$ and had acceptable intra-assay precision, with CV of 2.2 and $1.9 \%$ for samples with a plasma [prog] measured by RIA of 2.5 and $4.6 \mathrm{ng} / \mathrm{mL}$, respectively (Simontacchi et al., 1999). However, the ELISA overestimated plasma [prog] by 190 to $200 \%$ (mean 197\%) over an ELISA-measured range of 1.0 to $9.5 \mathrm{ng} / \mathrm{mL}$ when compared with a RIA (Simontacchi et al., 1999). Consequently, the plasma [prog] cut-points of $<3.90$, $<3.52$, and $<4.63 \mathrm{ng} / \mathrm{mL}$ for predicting parturition within 6,12 , or $24 \mathrm{~h}$ identified in this study could be adjusted to plasma [prog] cut-points of $<1.98,<1.79$, and $<2.35 \mathrm{ng} / \mathrm{mL}$ when plasma [prog] is measured by RIA. The latter cut-points approximate the plasma [prog] range observed in other studies of periparturient cows (Matsas et al., 1992; Birgel et al., 1994; Shenavai et al., 2012). Nevertheless, a low plasma [prog] appears to be a robust predictor of parturition within $24 \mathrm{~h}$, based on Se and Sp estimates of 0.90 and 0.91 (present study), and 0.87 and 0.91 (Matsas et al., 1992), respectively. Predictive performance was not improved as a test for calving within 6 or $12 \mathrm{~h}$, and accordingly, plasma [prog] is best used as a test for predicting calving within $24 \mathrm{~h}$.

In the present study, the plasma [cortisol]-time relationship over the $2 \mathrm{~d}$ before calving was similar to that observed previously (Hudson et al., 1976). An important finding was that plasma $[\text { gluc }]_{\mathrm{b}}$ and [gluc $]_{\mathrm{p}}$ were positively and linearly associated with plasma [cortisol] during the immediate periparturient period. Therefore, periparturient maternal hyperglycemia in the present study was most likely due to maternal hypercortisolemia, secondary to activation of the maternal HPA axis, presumably in response to the pain and stress of the first stage of parturition (Hudson et al., 1976; Patel et al., 1996). Primiparous cattle had higher mean plasma [cortisol], [gluc $]_{\mathrm{b}}$, and [gluc $]_{\mathrm{p}}$ than multiparous cattle in the last $2 \mathrm{~d}$ of gestation, suggesting a higher level of stress in primiparous cattle as these cattle were housed, fed, watered, and handled similarly to multiparous cattle. The mean $[\mathrm{gluc}]_{\mathrm{p}}$ at the time of calving in this study was approximately $100 \mathrm{mg} / \mathrm{dL}$ and similar to that reported in previous studies (Schwalm and Schultz, 1976; Bionaz et al., 2007; Garverick et al., 2013).

Diagnostic accuracy and usefulness are fundamental requirements of a diagnostic test. In the context of this study, diagnostic accuracy measures the ability of the test to predict calving within a specific time interval. Receiver operating characteristic plots provide the best test of diagnostic accuracy, because they communicate test performance over the complete range of operating conditions and decision thresholds (Zweig and Campbell, 1993). The best single summary statistic of receiver operating characteristic plots is the AUC, so the diagnostic accuracy of tests are best ranked on the basis of their AUC values (Zweig and Campbell, 1993). For example, the most accurate test for predicting parturition within $24 \mathrm{~h}$ in the present study was a decrease in plasma [prog] $(\mathrm{AUC}=0.96)$; the AUC for this test was numerically larger than those for a decrease in vaginal temperature ( $\mathrm{AUC}=0.79$ to 0.84 ), rectal temperature $(\mathrm{AUC}=0.73$ to 0.84; Burfeind et al., 2011), and ventral tail base surface temperature $(\mathrm{AUC}=0.88$ to 0.95; Koyama et al., 2018). Similarly, the most accurate tests for predicting parturition within $6 \mathrm{~h}$ in the present study were as follows: in heifers, an increase in [gluc $]_{\mathrm{b}}$ $(\mathrm{AUC}=0.96)$ or $[\mathrm{gluc}]_{\mathrm{p}}(\mathrm{AUC}=0.93)$; in multiparous cows, a decrease in plasma $[\mathrm{prog}](\mathrm{AUC}=0.91)$ and an increase in gluc $_{\mathrm{b}}(\mathrm{AUC}=0.86)$ or $[\mathrm{gluc}]_{\mathrm{p}}(\mathrm{AUC}=$ 0.84). For comparison, 1 study ranked the diagnostic accuracy of the following clinical signs for predicting parturition within $12 \mathrm{~h}$ : sacrosciatic ligament relaxation $(\mathrm{AUC}=0.78)$, teat filling $(\mathrm{AUC}=0.74)$, udder distention $(\mathrm{AUC}=0.73)$, vulva edema $(\mathrm{AUC}=0.67)$, tail relaxation $(\mathrm{AUC}=0.63)$, udder edema $(\mathrm{AUC}=$ 0.62 ), and vulva mucous secretion (AUC $=0.58$ (Streyl et al., 2011). The combination of 2 or 3 clinical signs produced a highest AUC of 0.82. Values for AUC can be compared statistically, but sample sizes greater than 350 are typically required to statistically differentiate between AUC values of 0.85 and 0.90 (Hanley and McNeil, 1982).

Diagnostic usefulness refers to the practical value of the information provided (Zweig and Campbell, 1993). The diagnostic usefulness of plasma [prog] when run as a laboratory test in a batch format is minimal, because the test is relatively expensive and blood samples need to be shipped to a laboratory. In most situations, the cow will have calved before the test results are available. For comparison, point-of-care diagnostic tests in resource-limited settings such as dairies need to be sufficiently accurate, have immediate clinical effect, and be cost-effective (Drain et al., 2014). On this basis, measurement of $[\mathrm{gluc}]_{\mathrm{b}}$ and $[\mathrm{gluc}]_{\mathrm{p}}$ have diagnostic 
usefulness, and measurement of $[\text { gluc }]_{\mathrm{b}}$ in particular is easily applied as a cow-side test.

The Precision Xtra blood glucose meter used in the present study was easy to use, provided quick results, and came at minimal cost (the glucometer cost $\$ 35$, and glucose strips were $\$ 0.30$ each). As well, the Precision Xtra meter has the ability to measure blood BHB (ketone) concentrations. Blood sampling from the coccygeal vessels is straightforward when the animal is restrained in a head gate, and use of a needle with a hub and no syringe provides sufficient blood volume for analysis. However, some producers might not be supportive of frequent blood draws from the coccygeal vessels. As an alternative, pin pricks to the tail or ear to obtain capillary blood could be performed, although studies on this method for glucose evaluation do not appear to have been completed in cattle. Handheld glucometer systems are susceptible to errors caused by temperature, humidity, patient hematocrit, improper calibration, use of expired reagent strips, and inappropriate blood droplet size or placement (Megahed et al., 2015). A minor problem the authors faced while conducting this study was using the glucometer in winter. Because the recommended operating temperature for the Precision Xtra is 10 to $50^{\circ} \mathrm{C}$, the glucometer stopped working in very cold ambient temperatures and had to be brought indoors to be warmed.

We elected not to report predictive values of a positive test $(\mathrm{PV}+)$ or a negative test $(\mathrm{PV}-)$ in the present study. These 2 indices are influenced by the prevalence of disease in the sample population, so they can only accurately summarize test performance when the study population is representative of the total population. In contrast, estimates for $\mathrm{AUC}, \mathrm{Se}, \mathrm{Sp}$, and +LR are characteristics of the test itself and are not influenced by disease prevalence.

The strengths of the present study were that it examined a relatively large number of dairy cattle in late gestation, compared primiparous and multiparous animals, and applied segmented linear and nonlinear mixed-model regression to accurately identify the time relative to parturition that plasma [prog] started to decrease and $[\mathrm{gluc}]_{\mathrm{b}}$ and $[\mathrm{gluc}]_{\mathrm{p}}$ began to increase. We also applied binomial logistic regression and segmented regression methods that accounted for repeated measures from the same cows. Limitations of the study were that it was based on only 1 herd, and that the method used to measure plasma [prog] could have had higher precision.

\section{CONCLUSIONS}

The present study showed that a decrease in plasma [prog] starting at $35 \mathrm{~h}$ before calving should be viewed as the initiator of parturition from the maternal perspective. Stress associated with the first stage of parturition activates the maternal HPA axis, leading to hypercortisolemia and hyperglycemia. The most accurate diagnostic test for predicting calving within $24 \mathrm{~h}$ is low plasma [prog]; however, this test is not practical. Point-of-care testing to determine [gluc $]_{\mathrm{b}}$ in periparturient dairy cattle provides an accurate, practical, and low-cost cow-side method for predicting parturition within 6 and $12 \mathrm{~h}$.

\section{ACKNOWLEDGMENTS}

Funding for this study was provided, in part, by a Government Mission Program grant from the Cultural and Educational Bureau, the Embassy of the Arab Republic of Egypt (A. A. Megahed), and the Scholarship Division, Ministry of Education, Malaysia (M. W. H. Hiew). The authors state that they do not have any conflicts of interest.

\section{REFERENCES}

Ballinger, G. A. 2004. Using generalized estimating equations for longitudinal data analysis. Organ. Res. Methods 7:127-150. https:// doi.org/10.1177/1094428104263672.

Barrier, A. C., M. J. Haskell, A. I. Macrae, and C. M. Dwyer. 2012. Parturition progress and behaviours in dairy cows with calving difficulty. Appl. Anim. Behav. Sci. 139:209-217. https://doi.org/ 10.1016/j.applanim.2012.03.003.

Berglund, B., J. Philipsson, and O. Danell. 1987. External signs of preparation for calving and course of parturition in Swedish dairy cattle breeds. Anim. Reprod. Sci. 15:61-79. https://doi.org/10 .1016/0378-4320(87)90006-6.

Bionaz, M., E. Trevisi, L. Calamari, F. Librandi, A. Ferrari, and G. Bertoni. 2007. Plasma paraoxonase, health, inflammatory conditions, and liver function in transition dairy cows. J. Dairy Sci. 90:1740-1750. https://doi.org/10.3168/jds.2006-445.

Birgel, E. H., E. Grunert, and J. A. G. Soares. 1994. The preparatory phase of delivery in cattle, under consideration of the external signs of delivery and changes in progesterone to predicting the calving time. Dtsch. Tierarztl. Wochenschr. 101:355-359.

Bleul, U., S. Spirig, M. Hässig, and W. Kähn. 2006. Electrolytes in bovine prepartum mammary secretions and their usefulness for predicting parturition. J. Dairy Sci. 89:3059-3065. https://doi.org/10 .3168 /jds.S0022-0302(06)72580-2.

Burfeind, O., V. S. Suthar, R. Voigtsberger, S. Bonk, and W. Heuwieser. 2011. Validity of prepartum changes in vaginal and rectal temperature to predict calving in dairy cows. J. Dairy Sci. 94:5053-5061. https://doi.org/10.3168/jds.2011-4484.

Conley, A. J., E. L. Legacki, C. J. Corbin, S. Stanley, C. R. Dahlen, and L. P. Reynolds. 2019. Serum and tissue pregnanes and pregnenes after dexamethasone treatment of cows in late gestation. Reproduction 157:413-422. https://doi.org/10.1530/REP-18-0558.

Constable, P. D., K. W. Hinchcliff, S. H. Done, and W. Grunberg. 2017. General systemic states. Pages $84-87$ in Stress. Veterinary Medicine. 11th ed. Elsevier, St. Louis, MO.

Costa, J. B. G. Jr., J. K. Ahola, Z. D. Weller, R. K. Peel, J. C. Whittier, and J. O. J. Barcellos. 2016. Reticulo-rumen temperature as a predictor of calving time in primiparous and parous Holstein females. J. Dairy Sci. 99:4839-4850. https://doi.org/10.3168/jds $.2014-9289$.

Dixon, R., A. Hyman, E. Gurpide, I. Dyrenfurth, H. Cohen, E. Bowe, T. Engel, S. Daniel, S. James, and R. Vande Wiele. 1970. Feto- 
maternal transfer and production of cortisol in the sheep. Steroids 16:771-789. https://doi.org/10.1016/S0039-128X(70)80154-4.

Drain, P. K., E. P. Hyle, F. Noubary, K. A. Freedberg, D. Wilson, W. R. Bishai, W. Rodriguez, and I. V. Bassett. 2014. Diagnostic point-of-care tests in resource-limited settings. Lancet Infect. Dis. 14:239-249. https://doi.org/10.1016/S1473-3099(13)70250-0.

Dufty, J. H. 1971. Determination of the onset of parturition in Hereford cattle. Aust. Vet. J. 47:77-82. https://doi.org/10.1111/j.1751 -0813.1971.tb14742.x.

Erkens, J. H. F., S. J. Dieleman, R. A. Dressendörfer, and C. J. Strasburger. 1998. A time-resolved fluoroimmunoassay for cortisol in unextracted bovine plasma or serum with optimized procedures to eliminate steroid binding protein interference and to minimize nonspecific streptavidin-europium binding. J. Steroid Biochem. Mol. Biol. 67:153-161. https://doi.org/10.1016/S0960-0760(98)00083-1.

Garverick, H. A., M. N. Harris, R. Vogel-Bluel, J. D. Sampson, J. Bader, W. R. Lamberson, J. N. Spain, M. C. Lucy, and R. S. Youngquist. 2013. Concentrations of nonesterified fatty acids and glucose in blood of periparturient dairy cows are indicative of pregnancy success at first insemination. J. Dairy Sci. 96:181-188. https://doi.org/10.3168/jds.2012-5619.

Gillette, D. D. 1966. Placental influence on uterine activity in the cow. Am. J. Physiol. 211:1095-1098. https://doi.org/10.1152/ajplegacy 1966.211.5.1095.

Gillette, D. D., and L. Holm. 1963. Prepartum to postpartum uterine and abdominal contractions in cows. Am. J. Physiol. 204:11151121. https://doi.org/10.1152/ajplegacy.1963.204.6.1115.

Godden, W., and W. M. Allcroft. 1932. Changes in the composition of cow's blood at the time of calving and a comparison of the blood of the calf with that of its dam. Biochem. J. 26:1640-1646. https:/ /doi.org/10.1042/bj0261640.

Gonçalves, M. A., N. M. Bello, S. S. Dritz, M. D. Tokach, J. M. DeRouchey, J. C. Woodworth, and R. D. Goodband. 2016. An update on modeling dose-response relationships: Accounting for correlated data structure and heterogeneous error variance in linear and nonlinear mixed models. J. Anim. Sci. 94:1940-1950. https://doi .org/10.2527/jas.2015-0106.

Grimes, D. A., and K. F. Schulz. 2005. Refining clinical diagnosis with likelihood ratios. Lancet 365:1500-1505. https://doi.org/10.1016/ S0140-6736(05)66422-7.

Hankele, A. K., K. Rehm, J. Bérard, G. Schuler, L. Bigler, and S. E. Ulbrich. 2020. Progestogen profiling in plasma during the estrous cycle in cattle using an LC-MS based approach. Theriogenology 142:376-383. https://doi.org/10.1016/j.theriogenology.2019.10 .005.

Hanley, J. A., and B. J. McNeil. 1982. The meaning and use of the area under a receiver operating characteristic (ROC) curve. Radiology 143:29-36. https://doi.org/10.1148/radiology.143.1.7063747.

Hiew, M. W. H., A. A. Megahed, J. R. Townsend, W. L. Singleton, and P. D. Constable. 2016. Clinical utility of calf front hoof circumference and maternal intrapelvic area in predicting dystocia in 103 late gestation Holstein-Friesian heifers and cows. Theriogenology 85:384-395. https://doi.org/10.1016/j.theriogenology.2015.08.017.

Hudson, S., M. Mullford, W. G. Whittlestone, and E. Payne. 1976. Bovine plasma corticoids during parturition. J. Dairy Sci. 59:744746. https://doi.org/10.3168/jds.S0022-0302(76)84267-1.

Hunter, J. T., R. J. Fairclough, A. J. Peterson, and R. A. S. Welch. 1977. Foetal and maternal hormonal changes preceding normal bovine parturition. Acta Endocrinol (Copenh). 84:653-662. https: //doi.org/10.1530/acta.0.0840653.

Kindahl, H., B. Kornmatitsuk, and H. Gustafsson. 2004. The cow in endocrine focus before and after calving. Reprod. Domest. Anim. 39:217-221. https://doi.org/10.1111/j.1439-0531.2004.00506.x.

Koyama, K., T. Koyama, M. Sugimoto, N. Kusakari, R. Miura, K. Yoshioka, and M. Hirako. 2018. Prediction of calving time in Holstein dairy cows by monitoring the ventral tail base surface temperature. Vet. J. 240:1-5. https://doi.org/10.1016/j.tvjl.2018.08.006.

Landis, J. R., and G. G. Koch. 1977. The measurement of observer agreement for categorical data. Biometrics 33:159-174. https://doi .org/10.2307/2529310.
Lange, K., C. Fischer-Tenhagen, and W. Heuwieser. 2017. Predicting stage 2 of calving in Holstein-Friesian heifers. J. Dairy Sci. 100:4847-4856. https://doi.org/10.3168/jds.2016-12024.

Matsas, D. J., R. L. Nebel, and K. D. Pelzer. 1992. Evaluation of an on-farm blood progesterone test for predicting the day of parturition in cattle. Theriogenology 37:859-868. https://doi.org/10 .1016/0093-691X(92)90047-U.

Megahed, A. A., M. W. Hiew, S. A. El Badawy, and P. D. Constable. 2018b. Plasma calcium concentrations are decreased at least 9 hours before parturition in multiparous Holstein-Friesian cattle in a herd fed an acidogenic diet during late gestation. J. Dairy Sci. 101:1365-1378. https://doi.org/10.3168/jds.2017-13376.

Megahed, A. A., M. W. H. Hiew, and P. D. Constable. 2018a. Clinical utility of plasma fructosamine concentration as a hypoglycemic biomarker during early lactation in dairy cattle. J. Vet. Intern. Med. 32:846-852. https://doi.org/10.1111/jvim.15049.

Megahed, A. A., M. W. H. Hiew, D. Ragland, and P. D. Constable. 2019. Changes in skeletal muscle thickness and echogenicity, and plasma creatinine concentration as indicators of the rate of protein and intramuscular fat mobilization in periparturient dairy cows. J. Dairy Sci. 102:5550-5565. https://doi.org/10.3168/jds.2018-15063.

Megahed, A. A., M. W. H. Hiew, J. R. Townsend, and P. D. Constable. 2017. Characterization of the analytical performance of an electrochemical point-of-care meter for measuring $\beta$ - hydroxybutyrate concentration in blood and plasma from periparturient dairy cattle. Vet. Clin. Pathol. 46:314-325. https://doi.org/10.1111/vcp .12493 .

Megahed, A. A., M. W. H. Hiew, J. R. Townsend, J. B. Messick, and P. D. Constable. 2015. Evaluation of an electrochemical point-of-care meter for measuring glucose concentration in blood from periparturient dairy cattle. J. Vet. Intern. Med. 29:1718-1727. https://doi .org/10.1111/jvim.13608.

Miedema, H. M., M. S. Cockram, C. M. Dwyer, and A. I. Macrae. 2011. Changes in the behaviour of dairy cows during the $24 \mathrm{~h}$ before normal calving compared with behaviour during late pregnancy. Appl. Anim. Behav. Sci. 131:8-14. https://doi.org/10.1016/ j.applanim.2011.01.012.

NRC. 2001. Nutrient Requirements of Dairy Cattle. 7th rev. ed. National Academies Press, Washington, DC.

Patel, O. V., T. Takahashi, N. Takenouchi, M. Hirako, N. Sasaki, and I. Domekis. 1996. Peripheral cortisol levels throughout gestation in the cow: Effect of stage of gestation and foetal number. Br. Vet. J. 152:425-432. https://doi.org/10.1016/S0007-1935(96)80036-4.

Proverbio, D., R. Perego, E. Spada, G. Bagnagatti de Giorgi, A. Belloli, and D. Pravettoni. 2013. Comparison of VIDAS and radioimmunoassay methods for measurement of cortisol concentration in bovine serum. ScientificWorldJournal 216569. https://doi.org/10 $.1155 / 2013 / 216569$.

Saint-Dizier, M., and S. Chastant-Maillard. 2015. Methods and onfarm devices to predict calving time in cattle. Vet. J. 205:349-356. https://doi.org/10.1016/j.tvjl.2015.05.006.

Schober, P., and T. R. Vetter. 2018. Repeated measures designs and analysis of longitudinal data: If at first you do not succeed - try, try again. Anesth. Analg. 127:569-575. https://doi.org/10.1213/ ANE.0000000000003511.

Schuenemann, G. M., I. Nieto, S. Bas, K. N. Galvão, and J. Workman. 2011. Assessment of calving progress and reference times for obstetric intervention during dystocia in Holstein dairy cows. J. Dairy Sci. 94:5494-5501. https://doi.org/10.3168/jds.2011-4436.

Schuler, G., R. Fürbass, and K. Klisch. 2018. Placental contribution to the endocrinology of gestation and parturition. Anim. Reprod. 15(Suppl. 1):822-842. https://doi.org/10.21451/1984-3143 -AR2018-0015.

Schwalm, J. W., and L. H. Schultz. 1976. Relationship of insulin concentration to blood metabolites in the dairy cow. J. Dairy Sci. 59:255-261. https://doi.org/10.3168/jds.S0022-0302(76)84192-6.

Semambo, D. K. N., P. D. Eckersall, R. G. Sasser, and T. R. Ayliffe. 1992. Pregnancy-specific protein B and progesterone in monitoring viability of the embryo in early pregnancy in the cow after experimental infection with Actinomyces pyogenes. Theriogenology 37:741-748. https://doi.org/10.1016/0093-691X(92)90153-I. 
Shah, K. D., T. Nakao, and H. Kubota. 2006. Plasma estrone sulphate (E1S) and estradiol-17 $\beta$ (E2 $\beta$ ) profiles during pregnancy and their relationship with the relaxation of sacrosciatic ligament, and prediction of calving time in Holstein-Friesian cattle. Anim. Reprod. Sci. 95:38-53. https://doi.org/10.1016/j.anireprosci.2005.09.003.

Shenavai, S., S. Preissing, B. Hoffmann, M. Dilly, C. Pfarrer, G. R. Özalp, C. Caliskan, K. Seyrek-Intas, and G. Schuler. 2012. Investigations into the mechanisms controlling parturition in cattle. Reproduction 144:279-292. https://doi.org/10.1530/REP-11-0471.

Simontacchi, C., L. Marinelli, G. Gabai, G. Bono, and R. Angeletti. 1999. Accuracy in naturally occurring anabolic steroid assays in cattle and first approach to quality control in Italy. Analyst 124:307-312. https://doi.org/10.1039/a809373c.

Streyl, D., C. Sauter-Louis, A. Braunert, D. Lange, F. Weber, and H. Zerbe. 2011. Establishment of a standard operating procedure for predicting the time of calving in cattle. J. Vet. Sci. 12:177-185. https://doi.org/10.4142/jvs.2011.12.2.177.

Swets, J. A. 1988. Measuring the accuracy of diagnostic systems. Science 240:1285-1293. https://doi.org/10.1126/science.3287615.

Taverne, M. A. M., V. N. A. Breeveld-Dwarkasing, F. M. F. van Dissel-Emiliani, M. M. Bevers, R. De Jong, and G. C. Van der Wei- jden. 2002. Between prepartum luteolysis and onset of expulsion. Domest. Anim. Endocrinol. 23:329-337. https://doi.org/10.1016/ S0739-7240(02)00168-6.

Trefz, F. M., I. Lorenz, and P. D. Constable. 2018. Electrocardiographic findings in 130 hospitalized neonatal calves with diarrhea and associated potassium balance disorders. J. Vet. Intern. Med. 32:1447-1461. https://doi.org/10.1111/jvim.15220.

Wood, C. E. 1999. Control of parturition in ruminants. J. Reprod. Fertil. Suppl. 54:115-126.

Zweig, M. H., and G. Campbell. 1993. Receiver-operating characteristic (ROC) plots: A fundamental evaluation tool in clinical medicine. Clin. Chem. 39:561-577. https://doi.org/10.1093/clinchem/ 39.4.561

\section{ORCIDS}

A. A. Megahed (๑) https://orcid.org/0000-0003-2006-8873

P. D. Constable @ https://orcid.org/0000-0003-1929-2106 